\title{
Review Article \\ Current Status of Emerging PV Technologies: A Comparative Study of Dye-Sensitized, Organic, and Perovskite Solar Cells
}

\author{
Myrsini Giannouli 1 \\ Telou Agra 18, 26442, Patras, Greece \\ Correspondence should be addressed to Myrsini Giannouli; myrtwg@gmail.com
}

Received 12 December 2020; Revised 11 April 2021; Accepted 26 April 2021; Published 17 May 2021

Academic Editor: Kumarasamy Sudhakar

Copyright (C) 2021 Myrsini Giannouli. This is an open access article distributed under the Creative Commons Attribution License, which permits unrestricted use, distribution, and reproduction in any medium, provided the original work is properly cited.

\begin{abstract}
The imminent depletion of conventional energy sources has motivated the advancement of renewable energy technologies. Thirdgeneration photovoltaic technologies, such as dye-sensitized solar cells (DSSCs), organic solar cells (OSCs), and perovskite solar cells (PSCs), are being developed as alternatives to silicon solar cells. In recent years, there has been considerable interest in the market development of these emerging photovoltaic technologies, especially for sustainable solar energy applications. However, these technologies have not yet reached the maturity required for large-scale commercialization. Further research is required in order to improve the efficiency and stability of these devices, while keeping their production costs to a minimum. In this study, a comparative assessment of DSSCs, OSCs, and PSCs is conducted and the current state of the art of these promising technologies is investigated. Advanced techniques and research trends are examined from the perspective of novel materials, device modelling, and innovative device structures. The comparative advantages and limitations of each of these photovoltaic technologies are assessed in terms of device efficiency, durability, ease of fabrication, and performance-price ratio. Emphasis is placed on assessing the potential of these solar cell technologies for sustainable solar energy applications. Finally, the future outlook of these technologies is featured, and avenues for progress beyond the state of the art are explored.
\end{abstract}

\section{Introduction}

Fossil fuel resources are rapidly being depleted due to increasing global energy demand. It is estimated that the worldwide reserves of fossil fuels could only last 40 years for oil, 60 years for natural gas, and 200 years for coal [1]. Solar energy is a promising alternative to conventional energy sources, providing a source of energy that is both sustainable and environmentally friendly. The photovoltaic market has experienced a rapid growth over the past two decades, and so far, it has been largely dominated by silicon-based solar cells [2]. The cost of Si-based photovoltaic cells however is high, and large-scale industrial production of this technology requires extensive processing [3].

Third-generation photovoltaic technologies such as dyesensitized solar cells (DSSCs), organic solar cells (OSCs), and perovskite solar cells (PSCs) are being developed as alternatives to silicon solar cells [4]. In recent years, there has been increasing scientific interest in the development of these emerging photovoltaic technologies and their power conversion efficiencies (PCEs) have increased considerably, as shown in Figure 1.

The successful commercialization of emerging solar cell technologies however cannot be based solely on achieving high power conversion efficiencies (PCEs). These technologies need also to become cost-competitive with conventional power generation. The cost-effective deployment of photovoltaic (PV) systems is based on the following key requirements [6]:

(i) Minimum system cost

(ii) Maximum initial performance

(iii) Minimum loss of performance over time

These emerging photovoltaic technologies, although promising for sustainable solar energy applications, have not yet achieved large-scale commercialization [7]. Research 


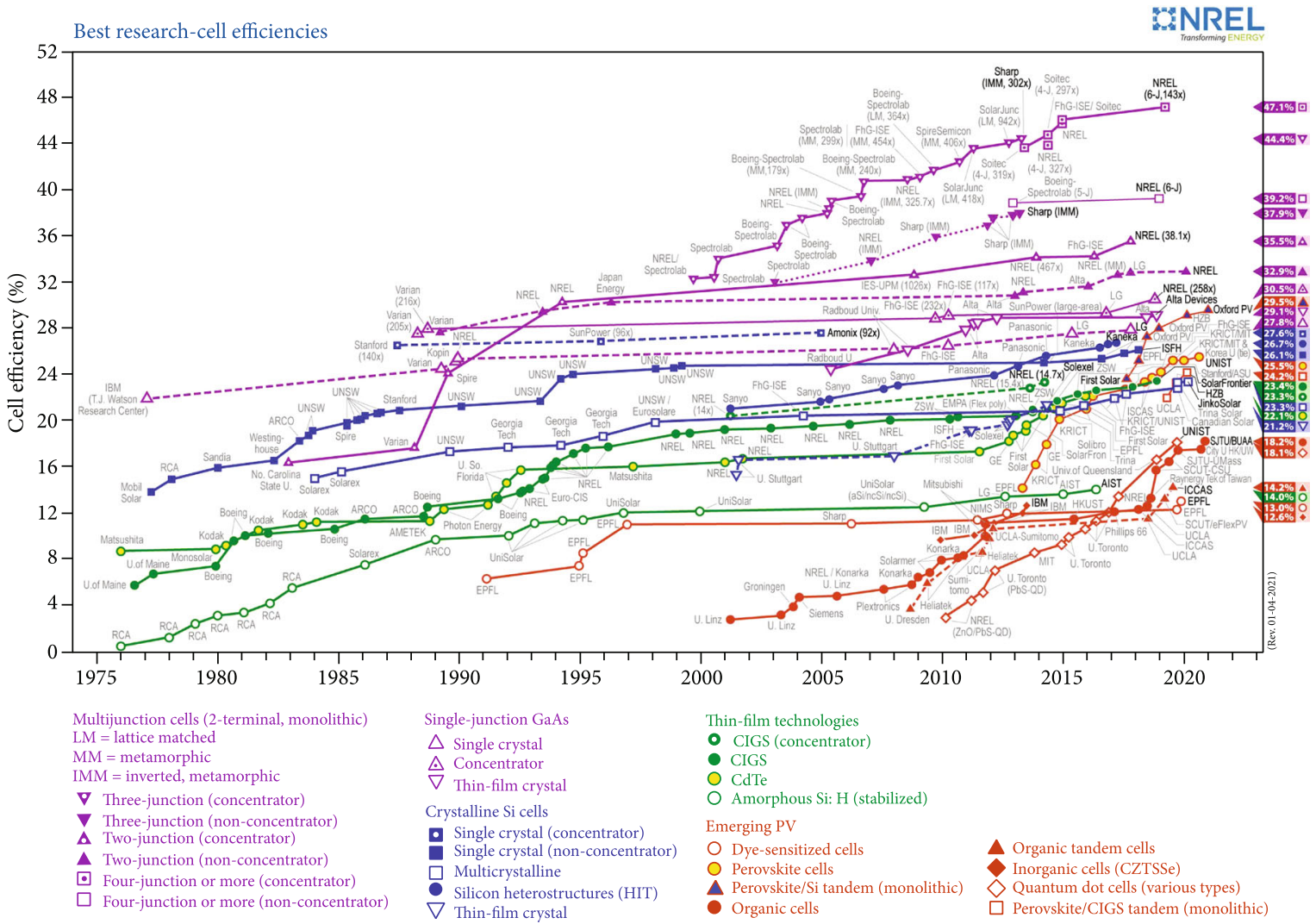

(a)

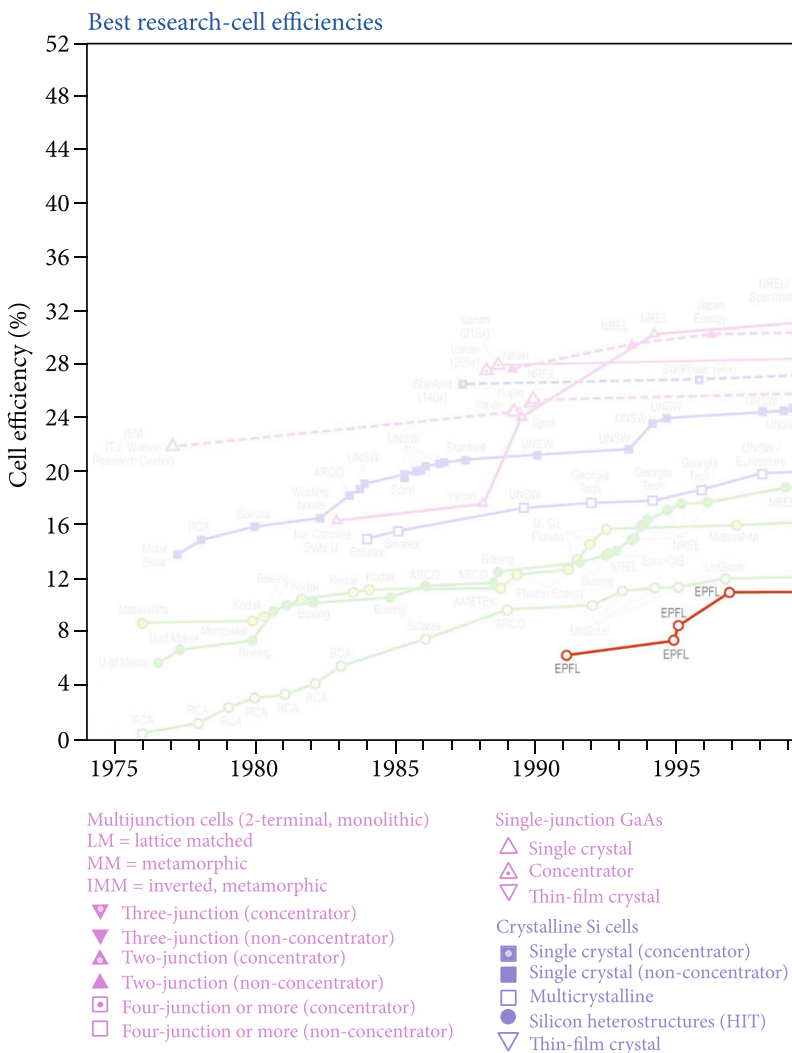
MNREL 
efforts are focused on increasing the efficiency and lifetime of these devices, combined with employing low-cost materials and processes.

In this review, we present a comparative assessment of the following photovoltaic technologies: dye-sensitized solar cells, perovskite solar cells, and organic solar cells. This first section of the paper provides an introduction of the three emerging technologies and highlights the requirements that need to be met for their large-scale commercialization. Sections 2-4 give an in-depth analysis of each of these technologies in turn, starting with DSSCs, continuing with PSCs, and closing with OSCs. The main part of the review is based on the three main pillars that are used to describe and compare these emerging technologies: their current status, future outlook, and sustainable applications. In Section 2 of the review, a brief historical overview is given for each of these technologies. The main device properties and features are also presented in the second section as well as common materials and methods used for the development of each solar cell technology. The third section of the paper presents the current state-of-the-art progress for the three emerging technologies and discusses the main challenges that need to be addressed for their commercialization, as well as the focus of future research trends in terms of novel materials, device modelling, and innovative device structures. Finally, the potential of each of these technologies for sustainable solar energy applications and products is presented in Section 4. Figure 2 outlines the structure and main features of this review, including the main sources from the literature that were cited in each section of the paper.

In terms of the originality of this work, this is the first review paper that provides an in-depth comparative assessment of DSSCs, PSCs, and OSCs with emphasis on their performance, advances beyond the state of the art, and potential for commercialization. The paper highlights recent scientific progress in improving not only the efficiency but also the stability and lifetime of these devices. An additional element of originality and scientific interest is presented by discussing the issues that need to be addressed in order to achieve large-scale commercialization of each of these emerging technologies and examining future research advances that are likely to provide solutions to these problems. A comparative assessment of potential applications and products is also conducted, with the aim of ascertaining the suitability of each of these emerging technologies for various sustainable solar energy applications, ranging from wearables and small-scale devices to large-scale applications, such as vehicles and buildings.

\section{Current Status}

2.1. Dye-Sensitized Solar Cells. Since the pioneering work of Grätzel and O'Regan in 1991 [8], dye-sensitized solar cells (DSSCs) with the highest efficiencies approximately $13 \%$ $[9,10]$ have gained considerable attention for their high efficiency, their potential low cost, and simple assembly technology.

In DSSCs, the conversion of visible light to electricity is achieved through the spectral sensitization of wide bandgap

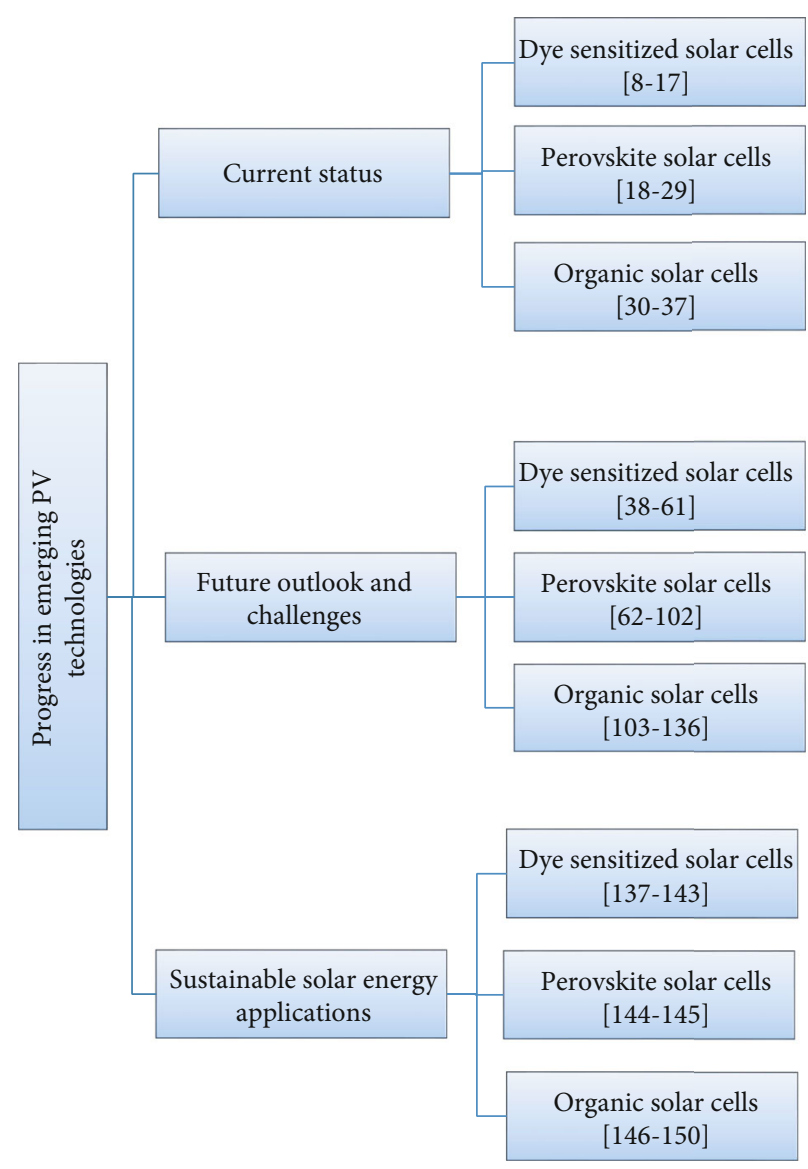

Figure 2: Outline of the main structure and literature citations of the paper.

semiconductors such as $\mathrm{TiO}_{2}, \mathrm{ZnO}$, and $\mathrm{SnO}_{2}$ [11]. The sensitization of the semiconductors with dyes is required to improve their ability to absorb solar radiation and inject electrons into the conduction band of the semiconductor [12]. Incident light on the sensitized semiconductor surface is absorbed by dye molecules, leading to the excitation of the dye at a singlet state. Excitation of the dye molecules is then followed by Interfacial Electron Transfer (IET) into the conduction band of the semiconductor (Figure 3(a)).

In DSSCs, a platinum or platinised counter electrode is used and a liquid, gel, or solid electrolyte containing a redox couple fills the space between the two electrodes [13] (Figure 3(b)). Each part of the DSSCs considerably affects device efficiency. For that reason, research efforts have been focused on optimizing not only each part of the device individually but also the way in which the various parts of the device correlate with each other [14]. Figure 3(a) shows the sensitization process and charge transfer mechanisms in DSSCs [12], while Figure 3(b) shows the basic structure of a dye-sensitized solar cell [13].

Photoanodes have been developed using a variety of film preparation techniques, such as sol-gel, hydrothermal, electrospinning, and atomic layer deposition. A wide range of semiconductor photoanodes have been used in DSSCs, such as nanoparticle, nanorod, and nanotube $[15,16]$. Various types of electrolytes have also been used in DSSCs. The main 


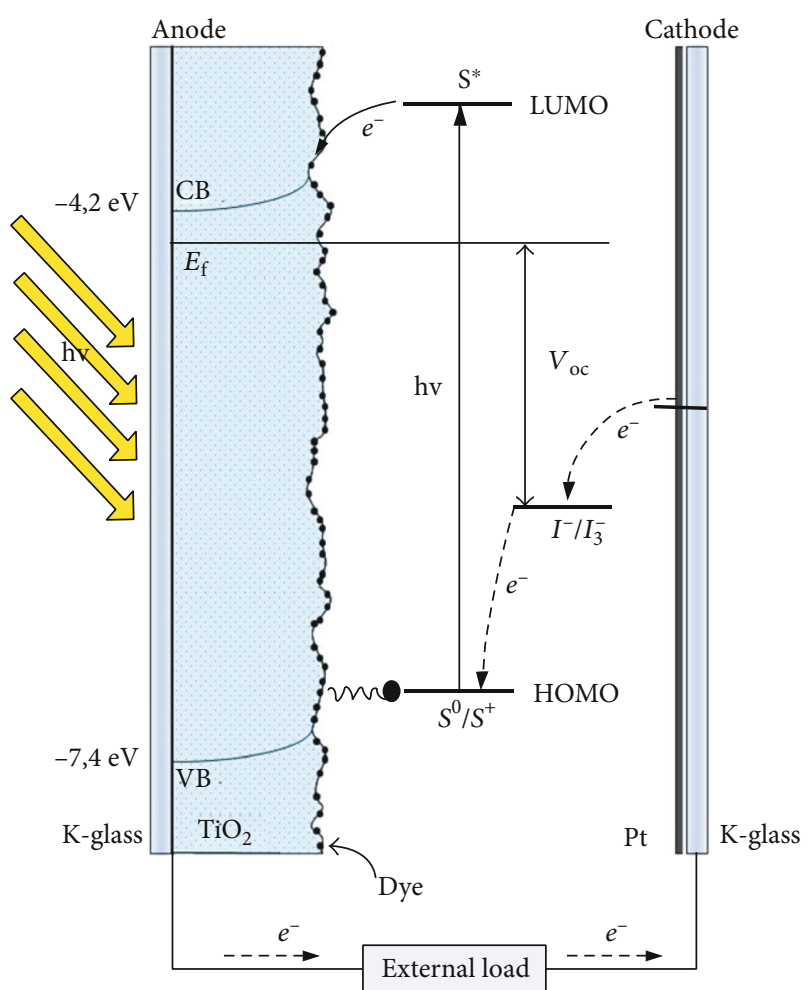

(a)

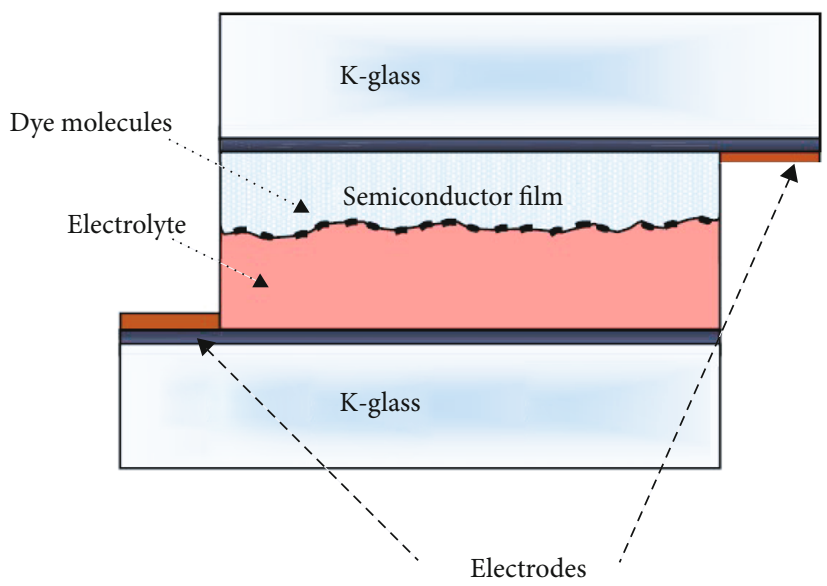

(b)

Figure 3: (a) Basic structure of a DSSC [13]. (b) Charge transfer mechanisms in DSSCs [12].

types of electrolytes used are liquid, quasi-solid, and solid electrolytes. The type of electrolyte affects device efficiency and stability considerably. Liquid electrolytes have yielded the highest efficiencies [10], but the lifetime of the resulting cells is rather limited.

The dye sensitizer used in DSSCs plays a very important role in light harvesting. Numerous dyes have been designed to broaden the absorption wavelength range of DSSCs and increase the overall efficiency of the cells. The most efficient (nonperovskite) sensitizers for wide bandgap semiconductors are metallo-organic ruthenium complexes such as N3, N719, and black dye, due to their high charge transfer efficiency to $\mathrm{TiO}_{2}$ and light absorption in the visible spectrum [17].

2.2. Perovskite Solar Cells. Recently, organic-inorganic hybrid perovskites have gained considerable research attention due to advantages such as high electron and hole mobility (10$\left.60 \mathrm{~cm}^{2} \mathrm{~V}^{-1} \mathrm{~s}^{-1}\right)$, bandgap tunability, long carrier diffusion length $(\sim 1 \mu \mathrm{m})$, and low exciton binding energy (30$50 \mathrm{meV}$ ) [18]. Apart from these advantages, perovskite solar cells (PSCs) can be produced using low-cost processes and materials and can even be manufactured on flexible substrates using roll-to-roll processes [9, 19]. PSCs thus have the potential to become one of the highest-efficiency and at the same time lowest-cost photovoltaic technologies on the market within the next few years and can even replace conventional Si-based solar cells. The market potential of PSCs though is as yet largely unexplored, and further research is required before this technology will become sufficiently mature for large-scale commercialization.
Organic-inorganic hybrid halide-based perovskites are a group of materials with the structure $\mathrm{ABX}_{3}$, where $\mathrm{A}$ is an organic cation $\left(\mathrm{CH}_{3} \mathrm{NH}_{3}{ }^{+}\right.$or $\left.\mathrm{NH}_{2} \mathrm{CH}_{3} \mathrm{NH}_{2}{ }^{+}\right)$, $\mathrm{B}$ is a divalent cation $\left(\mathrm{Pb}_{2}{ }^{+}\right.$or $\left.\mathrm{Sn}_{2}{ }^{+}\right)$, and $\mathrm{X}$ is a monovalent halide anion $\left(\mathrm{I}^{-}\right.$, $\mathrm{Br}^{-}$, or $\mathrm{Cl}^{-}$) [20].

Perovskite solar cells were originally developed from dyesensitized solar cells. In 2009, Kojima et al. used perovskite as a sensitizer in liquid-based $\mathrm{TiO}_{2}$ DSSCs and achieved a PCE of $3.2 \%$ and $3.8 \%$ for devices sensitized with $\left(\mathrm{CH}_{3} \mathrm{NH}_{3}\right) \mathrm{PbBr}_{3}$ and $\left(\mathrm{CH}_{3} \mathrm{NH}_{3}\right) \mathrm{PbI}_{3}$, respectively [21]. Two years later, Im et al. reached an efficiency of $6.5 \%$ by developing quantum dot solar cells using $\left(\mathrm{CH}_{3} \mathrm{NH}_{3}\right) \mathrm{PbI}_{3}$ as a sensitizer [22]. However, these liquid-based solar cells presented stability issues since perovskites tend to degrade rapidly in liquid electrolytes. This issue was resolved in 2012 by Kim et al. who replaced the liquid electrolyte with the solid material spiroMeOTAD (2,20,7,70-tetrakis(N,N-di-pmethoxyphenylamine)9,90-spiro-bifluorene), which acted as a hole-transporting material (HTM) [23]. These solid-state devices achieved a PCE of $9.7 \%$, and their increased stability marked a breakthrough for the PSC technology. The first PSC device architectures followed the typical structure of DSSCs in which the perovskite material played the role of the dye sensitizer. Device architectures then advanced to mesoscopic structures with the replacement of the liquid electrolyte with the aforementioned solid hole-transporting layer. Device architectures later evolved to planar structures with the perovskite material sandwiched between electron- and hole-transporting layers. Figure 4 shows various PSC device structures, including conventional $n-\mathrm{i}-\mathrm{p}$ or inverted $\mathrm{p}-\mathrm{i}-\mathrm{n}$ formation [18]. 

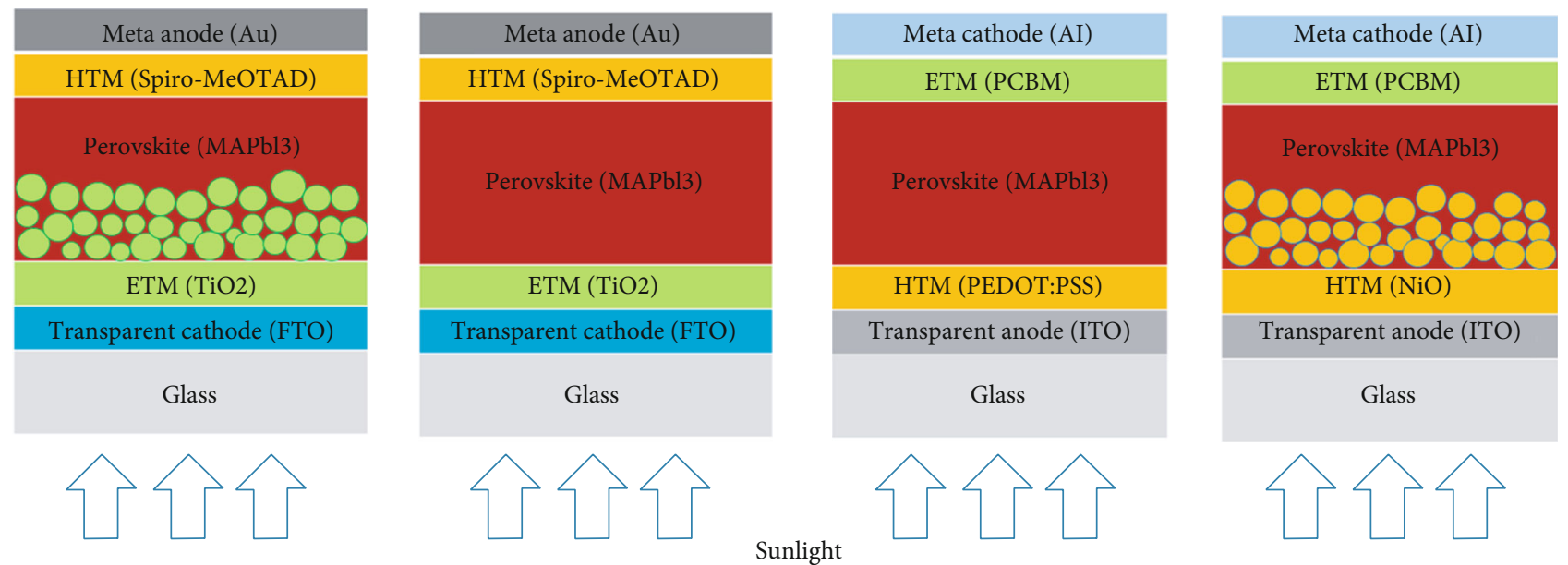

Figure 4: Perovskite solar cell architecture in the (a) n-i-p mesoscopic, (b) n-i-p planar, (c) p-i-n planar, and (d) p-i-n mesoscopic structures [18].

Femtosecond transient absorption spectroscopy studies were conducted in order to investigate electron injection dynamics in solid-state PSCs. Lee and coworkers [24] compared electron injection between devices containing a conducting $\left(\mathrm{TiO}_{2}\right)$ and a nonconducting $\left(\mathrm{Al}_{2} \mathrm{O}_{3}\right)$ layer. They did not observe significant differences between the two types of cells and even achieved efficiencies of $10.9 \%$ with $\mathrm{Al}_{2} \mathrm{O}_{3}$ based devices, indicating that an electron injection layer is not required in PSCs and that electron transfer can occur in the perovskite layer.

Within the next few years, perovskite solar cells have demonstrated a remarkable progress in efficiency. In 2013, organolead halide perovskite solar cells were produced with efficiencies exceeding $15 \%[25,26]$. A year later, a PCE of $16.2 \%$ was achieved using a mixed solvent to optimize the perovskite layers [27]. The same year, Zhou et al. optimized perovskite layers further, by lowering the defect density of the films. They used low-temperature processing steps to control humidity while the perovskite film formed from lead chloride and methylammonium iodide and achieved a maximum cell efficiency of $19.3 \%$ [28]. More recently, Saliba and coworkers [29] incorporated inorganic cesium in the perovskite layer and produced triple-cation perovskite compositions with a stabilized power output of $21.1 \%$ and $\sim 18 \%$ after 250 hours under operational conditions. This year, power conversion efficiencies of perovskite solar cells in excess of $25 \%$ have been reported and certified [5].

2.3. Organic Solar Cells. Organic photovoltaics represent a low-cost alternative to silicon solar cells, due to the high optical absorption coefficients of organic semiconductors, which enable the development of efficient photovoltaic devices with layers only a few nanometers thick [30]. Since polymers are usually processed in the liquid phase, simple printing and coating techniques can be utilized for their production. Organic solar cells have several promising advantages, such as their lightweight, large surface area, low production cost, and ability to be processed on flexible substrates [31]. The aforementioned advantages of OPV devices have led to increased interest in their development and, as a result, to

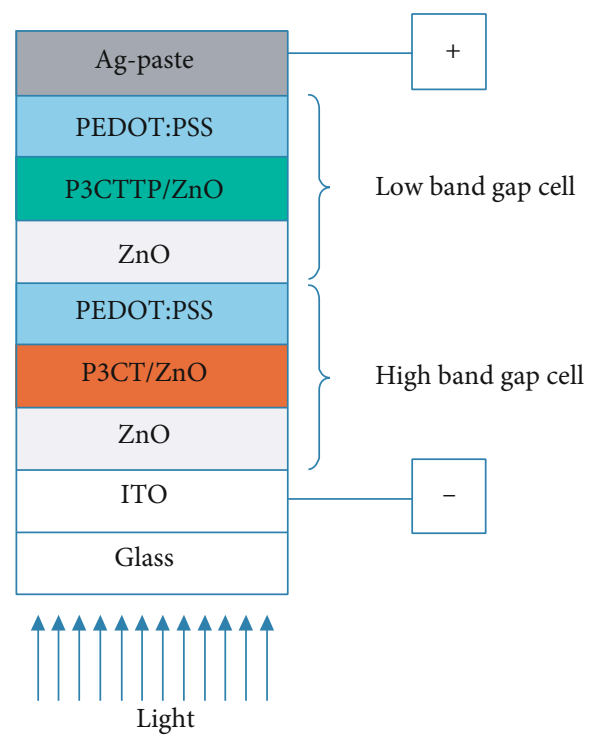

FIgURE 5: A schematic of an organic solar cell comprising eight layers with electrical connections [3].

considerable progress towards improving their performance [32]. The power conversion efficiency (PCE) of OPVs has increased from $6 \%$ in 2009 [33] to over 16\% within a decade [34]. Recently, efficiencies in excess of $18 \%$ were reported and verified for organic solar cells [5].

In organic solar cells, the absorbing layer is based on certain organic semiconductors (OSC). The basic structure of OPVs consists of photoactive organic layers comprised of p-type and n-type semiconducting polymers (Figure 5). For organic materials to become conducting or semiconducting, a high level of conjugation is required. The highest occupied molecular orbitals (HOMOs) and lowest unoccupied molecular orbitals (LUMOs) in these materials correspond to the respective valence and conduction bands of conventional inorganic semiconductors $[35,36]$. Between the highest occupied molecular orbital (HOMO) and lowest unoccupied molecular orbital (LUMO) of the OSC is an energy gap (the 
TABLE 1: Highest recorded efficiencies and device characteristics for DSSCs, PSCs, OPVs, and tandem PSCs [5].

\begin{tabular}{|c|c|c|c|c|c|}
\hline & $\begin{array}{l}\text { Efficiency } \\
(\%)\end{array}$ & Active layer/absorber & Carrier transporting material & $\begin{array}{c}\text { Innovative } \\
\text { materials/techniques }\end{array}$ & $\begin{array}{l}\text { Institution/ } \\
\text { company }\end{array}$ \\
\hline DSSC & 13.0 & $\begin{array}{l}\mathrm{TiO}_{2} \text { dye-sensitized } \\
\text { semiconductor }\end{array}$ & $\begin{array}{l}\text { Cobalt redox couple } \\
\text { electrolyte }\end{array}$ & $\begin{array}{c}\text { Panchromatic porphyrin } \\
\text { sensitizers }\end{array}$ & EPFL \\
\hline PSC & 25.2 & FAPbI 3-based perovskite & Spiro-MeOTAD & $\begin{array}{l}\text { Minimizing the deformation of } \\
\text { photoactive layers by changing } \\
\text { the type and ratio of ions }\end{array}$ & UNIST \\
\hline $\begin{array}{l}\text { Tandem } \\
\text { PSC/Si }\end{array}$ & 29.5 & $\begin{array}{l}\text { Monolithic perovskite } \\
\mathrm{PbI}_{2} \text {-based top cell/Si } \\
\text { bottom cell }\end{array}$ & $\begin{array}{c}\text { Methyl-substituted } \\
\text { carbazole monolayer/ } \mathrm{C}_{60}\end{array}$ & $\begin{array}{l}\text { Self-assembled } \\
\text { carbazole-based } \\
\text { monolayer with methyl } \\
\text { group substitution }\end{array}$ & Oxford PV \\
\hline $\begin{array}{l}\text { Tandem } \\
\text { PSC/CIGS }\end{array}$ & 24.2 & $\begin{array}{l}\text { Monolithic two-terminal } \\
\text { triple-cation PSC/CIGS }\end{array}$ & $\begin{array}{c}\text { Poly [bis }(4-\text { phenyl }) \\
\text { (2,4,6-trimethylphenyl)amine] } \\
\text { (PTAA)/C } 60\end{array}$ & $\begin{array}{l}\text { Rubidium-based } \\
\text { self-assembled } \\
\text { monolayer }\end{array}$ & HZB \\
\hline OPV & 18.2 & PBDB-T-2F:BTP-eC9 & PEDOT:PSS & $\begin{array}{l}\text { Chlorinated nonfullerene } \\
\text { acceptor }\end{array}$ & SJTU/BUAA \\
\hline
\end{tabular}

bandgap of the semiconductor). A high level of conjugation lowers the bandgap and allows electron excitation by visible light from HOMO to LUMO.

Electron donor materials (p-type polymers) originally used in OPVs included poly(p-phenylenevinylene) (PPV), poly(2-methoxy-5-(2-ethylhexyloxy)-1-4-phenylenevinylene) (MEH-PPV) [36], and, more recently, poly(3-hexylthiophene) (P3HT) [37]. The most common organic acceptors (n-type organic semiconductors) in OPVs were originally fullerenebased materials, such as [6,6]-phenyl-C61-butyric acid methyl ester (PCBM) [2].

In most OPV devices, poly(ethylenedioxythiophene)poly(styrenesulfonic acid) (PEDOT:PSS) was used for the transfer of holes between the transparent electrode and the active layer for normal structures and between the metal electrode and the active layer for inverted structures. PEDOT:PSS is a hole-transporting layer (HTL) that blocks electrons while transporting holes to the transparent anode of the OSCs, thus enhancing charge collection [2].

Table 1 shows comparative efficiencies and device characteristics for cells with the highest certified efficiency to date, for DSSCs, PSCs, OPVs, and tandem PSCs [5].

\section{Future Outlook and Challenges}

3.1. Dye-Sensitized Solar Cells. The efficiency of DSSCs has not increased significantly over the past few years (see Figure 1). There are several reasons for this lack of progress in the area of DSSCs, such as inherent limitations imposed by the materials, interfaces, and device architectures of DSSCs [38]. There has also been a shift of scientific interest in other promising solar cell technologies, especially in perovskite cells, which are considered the successors of DSSCs, since perovskite materials were originally used as sensitizers in DSSCs. However, there are still areas of interest in the future development of DSSCs that are being explored with the aim of improving their performance.

One of the most important issues that hinder the commercialization of DSSCs is their low stability [39]. Liquid electrolytes containing a redox couple, such as iodide/triio- dide, tend to evaporate easily, so a number of solid-state electrolytes have been developed in order to limit the stability issues caused by the evaporation of liquid electrolytes [40, 41]. In DSSCs, the liquid redox electrolyte can be replaced by a solid hole-transporting material in order to make solid-state DSSCs [42]. Promising results have been reported with molecular organic hole conductors such as spiro-MeOTAD, conduction polymers such as PEDOT, and metal complexes [43]. Polymer gel electrolytes containing redox couples (such as poly(acrylonitrile), poly(vinyl chloride), and poly(vinylidene fluoride)) have been used as quasisolid-state electrolytes to overcome the volatilization and leakage problems of liquid electrolytes [44]. Devices developed using solid electrolytes have shown relatively high stability but not as high efficiency as those filled with liquid electrolytes (13.0\% PCE) [45]. Recent optimization led to a recorded efficiency of $11.7 \%$ [41]. In addition, a number of sealing techniques and sealant materials, such as Surlyn ${ }^{\circledR}$ and Bynel ${ }^{\circledR}$ foils, have been employed to limit the evaporation of liquid electrolytes and increase device lifetime [46].

In terms of the dye sensitizer used, a large number of dyes have been developed and tested for use in dye-sensitized solar cells. As mentioned above, amongst the most efficient dye sensitizers are metallo-organic ruthenium complexes. Metal-free natural dyes, such as porphyrins, or coumarins have also been used successfully for the sensitization of semiconductor films in DSSCs. These dyes do not yield efficiencies as high as those achieved using ruthenium complexes but are more environmentally friendly and tend to have lower toxicity compared to $\mathrm{Ru}$-based complexes. In addition, many research efforts are focused on the synthesis of novel dyes for dye-sensitized solar cells. A number of novel dyes have been developed and tested for DSSCs, with promising results, such as carbazole, fluorine, indolin, oligothiophene, or boradiazaindacene- (BODIPY-) based dyes [46].

The ideal sensitizer for DSSCs should be panchromatic, absorbing all light below a threshold wavelength of approximately $920 \mathrm{~nm}$. However, each dye individually absorbs only a small portion of the visible spectrum of solar radiation, thus limiting the light-harvesting ability of the cells. Alternatively, 
cosensitization with two or more dyes, which have complementary absorption spectra, can be used to increase the range of absorption of the solar cells. This results in the conversion of photons into electrons at a wider region of the solar spectrum. Cosensitization thus increases the incident photon-tocurrent efficiency (IPCE) and consequently the current produced by the device [47]. Cosensitization is a successful way to improve the efficiency of DSSCs, and recording devices are usually based on cosensitized solar cells [46, 48]. Zuo and coworkers [49] developed a blend of N3 dye with a small quantity of squarylium cyanine (SQC). They reported an increase in the efficiency of $\mathrm{TiO}_{2}$ cells sensitized with this dye blend to over $10 \%$, due to increased dye regeneration in the dye blend. Yum and coworkers [50] also used a squaraine dye to sensitize solid-state $\mathrm{TiO}_{2}$ cells together with the dye N877 and reported an efficiency of $1.8 \%$ for the cosensitized cells, which was over $20 \%$ higher than the efficiency of cells sensitized with each single dye. Ogura et al. [51] used a blend of two dyes with complimentary absorption spectra (D131 and black dye) to sensitize $\mathrm{TiO}_{2}$ films and achieved efficiencies of the order of $11 \%$, which was higher than the efficiency of cells sensitized with each one of the dyes. Similarly, Saxena et al. obtained a $4.7 \%$ efficiency for $\mathrm{TiO}_{2}$ cells sensitized with a mixture of $\mathrm{N} 3$ and a rhodamine dye and reported a considerable increase in the performance of the cells compared to those sensitized with a single dye [52]. Another research group [53] developed a blend of five different dyes with complementary absorption spectra. $\mathrm{ZnO}$ films sensitized with this blend had an efficiency of approximately $7.9 \%$, which was higher than the efficiency achieved with each individual dye. Porphyrin dyes have also been used successfully in cosensitization. Sharma et al. [4] synthesized a novel porphyrin dye consisting of a zinc-metallated porphyrin unit and used it to sensitize $\mathrm{TiO}_{2}$ films, resulting in a PCE of $4.72 \%$. When this dye was used together with a tertiary aryl-amine D, which exhibits complementary light absorption characteristics with the porphyrin dye, the solar cell efficiency was increased to $7.34 \%$. Shibayama et al. [54] combined a black dye with an organic dye possessing a pyridine-binding group and demonstrated that the dyes adsorbed to different binding sites, thus increasing dye loading and cell performance.

Most research efforts on the cosensitization of DSSCs are focused on developing a dye cocktail with panchromatic absorption properties. Alternatively, sequential cosensitization can be used, in which the semiconductor is sensitized with one dye after another. Fan et al. reported that the order of sensitization affects the efficiency of DSSCs considerably. They achieved efficiencies of up to $8.14 \%$ by sequential cosensitization of $\mathrm{TiO}_{2}$ films with porphyrin and organic dyes and found that cosensitization can increase device efficiency up to $61 \%$ compared with devices sensitized with a single dye [55]. Their conclusions agree with our own findings [56], in which we investigated the cosensitization of $\mathrm{ZnO}$ films by organic dyes, such as porphyrins and coumarins. We found that sequential sensitization with three organic dyes can yield efficiencies over 4 times greater than those of cells sensitized by any of the single dyes and almost twice as high as those of cells sensitized with a blend of these dyes. We observed that the order of sensitization and the sen- sitization time play a significant role in increasing device efficiency by enhancing device IPCE and dye loading. Cosensitization can thus be optimized to achieve maximum light harvesting and improve device performance.

Another approach that has been used in recent years to increase the efficiency of DSSCs is the incorporation of quantum dot (QD) nanoparticles into the cell. This process is based on the plasmonic resonance that occurs when electrons at the interface between negative and positive permittivity materials are excited by incident light. Metal nanoparticles, such as $\mathrm{Ag}$ or $\mathrm{Au}$, are incorporated into the photoanode of the DSSCs in order to create a nanoprism that scatters light within the device. Jun et al. [57] incorporated Au nanoparticles into the commercial $\mathrm{TiO}_{2}$ nanopowder that was used to create the photoanode and achieved an increase in efficiency by approximately $50 \%$ compared to devices that did not contain $\mathrm{Au}$ nanoparticles. Bakr et al. incorporated $\mathrm{Au}$ nanoparticles prepared by pulsed Nd:YAG laser ablation at $1064 \mathrm{~nm}$ in a solution of Z907 dye [58]. The addition of the synthesized gold nanoparticles to the dye resulted in an increase in device efficiency from $1.284 \%$ to $2.357 \%$, due to increased light absorption from the gold nanoparticles. More recently, Sim et al. [59] achieved an increase in device efficiency from 6.3 to $7.2 \%$ by developing a three-dimensional transparent photoanode and a scattering layer, which was used to trap and disperse incident light within the device.

Table 2 summarizes some of the main materials, components, and techniques used for the development of novel dyesensitized solar cells with improved device performance.

3.2. Perovskite Solar Cells. The performance of perovskite solar cells has been improving rapidly, with efficiencies in excess of $28 \%$ predicted in the near future for perovskite PSCs with ideal transport layers [60]. The performance of PSCs can be improved considerably through the optimization of the various materials and processes involved in their development [61]. Currently, many research efforts are focused on improving the morphology and stability of the perovskite layer. In terms of morphology, perovskite films should ideally be compact and free of pinholes, contain large grains, and have a high degree of crystallinity. The morphology of the perovskite layer can be controlled through a number of processes, such precursor solution processing and aging [62], perovskite film annealing [63], and incorporation of additives in the perovskite material [64]. It has also been demonstrated that optimizing the crystallinity of the perovskite absorption layer is crucial to the development of perovskite solar cells with high power conversion efficiencies [65], as improved crystallinity leads to enhanced film uniformity, thus increasing device efficiency [66].

Another area of interest is interface engineering, and several research groups report improved device efficiency and stability through interface optimization. Wu et al. introduced a thin layer of poly(ethylene oxide) as an interfacial layer in formamidinium-cesium-based PSCs, in order to modify the energy levels at the interface between the perovskite and the carbon electrode [67]. They report an increase of $2.5 \%$ in the efficiency of the PSCs that contain the interfacial level, due to improved energy alignment at the perovskite/carbon 
TABLE 2: Novel materials and methods used for the development of DSSCs.

\begin{tabular}{|c|c|c|c|}
\hline Photoanodes & Electrolytes containing redox couple & Sensitizers & Sensitization techniques \\
\hline $\begin{array}{l}\text { Wide bandgap semiconductors } \\
\left(\mathrm{TiO}_{2}, \mathrm{ZnO} \text {, and } \mathrm{SnO}_{2}\right)\end{array}$ & $\begin{array}{l}\text { Liquid electrolytes } \\
\text { (e.g., iodide/triiodide) } \\
\text { up to } 13.0 \% \text { PCE }\end{array}$ & $\begin{array}{c}\text { Metallo-organic } \\
\text { ruthenium complexes } \\
\text { (N3, N719, and black dye) }\end{array}$ & $\begin{array}{l}\text { Cosensitization using dyes } \\
\text { with complementary } \\
\text { absorption spectra }\end{array}$ \\
\hline $\begin{array}{l}\text { Different photoanode layer } \\
\text { morphologies such as } \\
\text { nanoparticle, nanorod, } \\
\text { and nanotube }\end{array}$ & $\begin{array}{c}\text { Solid electrolytes } \\
\text { (spiro-MeOTAD, PEDOT, } \\
\text { and metal complexes) } \\
\text { up to } 11.7 \% \text { PCE }\end{array}$ & $\begin{array}{l}\text { Natural or organic dyes } \\
\text { (porphyrins, coumarins, } \\
\text { rhodamines, etc.) }\end{array}$ & $\begin{array}{c}\text { Dye combinations: } \\
\text { Ru complexes/squaraine dyes, } \\
\text { N3/Rhodamine B, tertiary } \\
\text { aryl-amine D/zinc-metallated } \\
\text { porphyrin-11\% PCE }\end{array}$ \\
\hline \multirow{2}{*}{$\begin{array}{l}\text { Film deposition techniques: } \\
\text { sol-gel, hydrothermal, } \\
\text { electrospinning, and atomic } \\
\text { layer deposition }\end{array}$} & \multirow{2}{*}{$\begin{array}{l}\text { Quasi-solid electrolytes } \\
\text { (e.g., poly(acrylonitrile), } \\
\text { poly(vinyl chloride), and } \\
\text { poly(vinylidene fluoride)) }\end{array}$} & $\begin{array}{l}\text { Novel synthetic dyes } \\
\text { (e.g., chlorin, indolin, } \\
\text { or BODIPY-based) }\end{array}$ & $\begin{array}{l}\text { Sequential cosensitization } \\
\text { with multiple dyes (e.g., } \\
\text { porphyrins, coumarins, } \\
\text { and Ru complexes) up } \\
\text { to } 8.14 \% \text { PCE }\end{array}$ \\
\hline & & $\begin{array}{c}\text { Synthesized panchromatic } \\
\text { dye sensitizers up to } \\
13.0 \% \text { PCE }\end{array}$ & $\begin{array}{l}\text { Incorporation of QD } \\
\text { nanoparticles, such as Ag } \\
\text { or Au up to } 7.2 \% \text { PCE }\end{array}$ \\
\hline
\end{tabular}

interface. Lu et al. [68] developed $\mathrm{cm}$-sized PSCs with power conversion efficiencies of up to $20 \%$ using benzenethiol molecules to modify the interface between the perovskite layer and the spiro-MeOTAD hole-transporting layer. The resulting devices showed improved efficiency and stability due to enhanced charge extraction and reduced charge recombination.

In regard to the hole-transporting layer, research trends focus on the development of inorganic p-type semiconductor materials to replace the organic hole-transporting layer that is commonly used in PSCs. Inorganic materials, such as $\mathrm{CuI}, \mathrm{NiO}$, and $\mathrm{CuSCN}$, exhibit several advantages over organic materials, such as wide bandgap, high hole mobility, and simple processing. Seo et al. [69] used undoped $\mathrm{NiO}$ films as the hole-transporting layer in hybrid organicinorganic PSCs and achieved power conversion efficiencies of $16.4 \%$. Zhang et al. reported power conversion efficiencies of $18.5 \%$ for perovskite solar cells with the inorganic p-type semiconductor $\mathrm{CuGaO}_{2}$ as the hole-transporting layer [70]. The resulting PSCs had also high long-term stability, retaining high efficiency after 30 days of continuous operation in ambient conditions.

Cosensitization can also be used to improve the lightharvesting ability and PCE of perovskite solar cells. The use of a dye sensitizer is not required in PSCs, since perovskite materials can simultaneously act as the absorber material and the electron injection layer. However, a dye sensitizer can be used in order to broaden the absorption wavelength range of PSCs. In PSCs, the absorption onset occurs at a wavelength of $800 \mathrm{~nm}$, as measured by incident photon-toelectron conversion efficiency (IPCE) [71]. At this wavelength, the theoretical maximum photocurrent density is $27.2 \mathrm{~mA} \mathrm{~cm}^{-2}$ when assuming no light loss by reflection at the transparent conductive substrate. Light loss should be taken into account though practical devices, which leads to a maximum photocurrent in the range of $23.1-21.8 \mathrm{~mA} \mathrm{~cm}$ 2 [72]. Cosensitization can increase the range of absorption of perovskite solar cells, resulting in the conversion of photons into electrons at a wider region of the solar spectrum
[52]. This can enhance the incident photon-to-current efficiency and consequently the current produced by the device [47]. Zhang et al. used metallophthalocyanines to sensitize $\mathrm{CH}_{3} \mathrm{NH}_{3} \mathrm{PbI}_{3}$ solar cells and reported a PCE of almost $14 \%$, which was increased by $28 \%$ compared to the efficiency of the devices that used only the perovskite as the absorption material [73]. They attributed the enhanced efficiency of the cosensitized devices to charge injection occurring from both sensitizers, possible energy transfer from high energy perovskite to the lower energy dye, and potential decrease in series resistance. Recently, Balachandran et al. [74] developed methyl ammonium lead bromide $\left(\mathrm{CH}_{3} \mathrm{NH}_{3} \mathrm{PbBr}_{3}\right)$ perovskites doped with the N719 dye. They reported a remarkable increase in efficiency, from $1 \%$ for the undoped cells to $4.8-6.8 \%$ for devices cosensitized with N719, demonstrating the high potential of cosensitization in improving device performance.

Perovskite materials have certain properties that make them ideal for use in tandem with other solar cell technologies: complementary solar spectral absorption, bandgap tunability, and ease of processing and process compatibility with silicon and CIGS ( $\left.\mathrm{Cu}(\mathrm{In}, \mathrm{Ga}) \mathrm{Se}_{2}\right)$ technologies.

Recently, two spin-off technologies of perovskite solar cells have attracted the attention of the scientific community: perovskite/Si tandem and perovskite/CIGS tandem solar cells. From Figure 1(b), it can be observed that, although these technologies have been investigated for only a few years, the efficiencies recorded for these cells are very high and rising at an impressive rate. Currently, Oxford PV holds the highest certified efficiency recorded for perovskite/Si tandem cells and the Helmholtz-Zentrum Institute in Berlin for perovskite/CIGS cells, with $29.5 \%$ and $24.2 \%$, respectively [5]. There are two common tandem solar cell architectures: mechanically stacked and monolithic. A mechanically stacked cell consists of two independent solar cells one on top of the other, while a monolithic cell is comprised of a two-terminal device built in series on a single substrate. The monolithic structure is the one most commonly used in industry and preferred from a technological and performance perspective. 
Monolithic perovskite/Si tandem cells have attracted huge interest because they capitalize on the mature silicon solar cell industry and also have the potential to overcome the theoretical efficiency limit of single-junction silicon solar cells [75]. Perovskite/Si solar cells comprise two cells that work in tandem: a top perovskite cell and a bottom Si cell [76]. Silicon converts mostly the red part of the solar spectrum to electricity, while perovskite materials utilise the blue portions of the spectrum. A tandem solar cell made of stacked silicon and perovskite can thus achieve higher efficiency than each individual cell on its own, and solar cell efficiencies of over $30 \%$ can be achieved [77]. Photocurrent matching between the two subcells is a prerequisite to achieve high efficiency in monolithic tandem cells [78]. The efficiency of a perovskite/Si monolithic tandem cell can be enhanced by adjusting the electrical and optical properties of the electron transport layer and optimizing the bandgap and the optical density of the perovskite absorber [79].

Monolithic perovskite/CIGS tandem solar cells have a similar architecture to perovskite/Si cells, with a perovskite top cell fabricated directly on an as-grown CIGSe bottom cell [80]. Semitransparent perovskite materials have been developed using low-temperature processes and used in tandem with CIGS solar cells, reporting power conversion efficiencies in excess of $20 \%$ [81]. The combination of perovskite and CIGS materials with complementary absorption spectra can potentially lead to PCEs over $30 \%$. To ensure optimum device efficiency, the interconnecting layer in tandem cells should have effective electrical connection as well as high optical transparency [82].

Even though rapid progress has been demonstrated in the development of highly efficient perovskite solar cells, a number of issues need to be addressed before they can become a market-competitive technology. The main drawbacks of perovskite solar cells are their poor stability and high toxicity. The low stability of PSCs, especially in conditions of high moisture, extensive illumination, and high temperatures, is one of the biggest challenges faced for the successful commercialization of this technology. Several studies are currently focused on addressing these issues by studying the degradation mechanisms in perovskite materials and other device layers. Research towards improving the stability of these cells is focused on two main strategies: (a) improving the intrinsic stability of the device and (b) protecting the device via external means. The stability of PSCs can be improved intrinsically especially by changing the component materials of the absorbing layer. The organic cations most commonly used in the absorber, especially methylammonium, are susceptible to moisture and heat degradation [83]. Devices that incorporate mixed-cation systems, such as rubidium or caesium, into the perovskite material have shown increased efficiency and stability [29]. Mixed-halide and mixed-cation systems have also exhibited high stability. Saliba et al. reported a $19 \%$ power conversion efficiency for mixed-halide and quadruple-cation PSCs that retained 95\% of their efficiency for 500 hours under illumination at $85^{\circ} \mathrm{C}$ [84]. More recently, Matsui et al. reported efficiencies in excess of $20 \%$, for $\mathrm{cm}$-sized cells that retained $92 \%$ of their power conversion efficiencies after $1000 \mathrm{~h}$ in high heat/mois- ture conditions. They incorporated $\mathrm{Rb}$ in the perovskite absorber layer, which increased the thermal stability of the resulting solar cells [85].

The optimization of interfacial layers can also lead to increased stability, for example, by replacing materials that are sensitive to UV radiation, such as $\mathrm{TiO}_{2}$, with more UVstable interfacial layers, such as $\mathrm{SnO}_{2}$. Zhu et al. [86] introduced ammonium chloride at the $\mathrm{TiO}_{2}$ /perovskite interface, thereby improving charge extraction and increasing device efficiency and stability. Christians et al. [87] developed a cell with optimized interfacial layers that retained $94 \%$ of its peak efficiency after 1000 hours of unencapsulated operation in ambient air conditions.

Many research efforts also concentrate on improving the stability of PSCs through external modifications, such as the encapsulation of the cell. A very effective method of encapsulation is to cover the cell with a glass film and seal it with an epoxy resin. However, this technique is not compatible with roll-to-roll processing and thus not recommended for largescale commercial devices. Polymer sealants on the other hand have been used successfully to increase the stability of perovskite solar cells. A lifetime of 10,000 hours has been reported using polyethylene terephthalate encapsulation [88], while cells coated with a layer of luminescent photopolymer maintained 3-month lifetimes in outdoor conditions [89]. Bush et al. [90] reported a power conversion efficiency of $23.6 \%$ for a monolithic perovskite/silicon tandem cell that operated successfully for 1000 hours under a damp heat test $\left(85^{\circ} \mathrm{C}\right.$ and $85 \%$ relative humidity). In addition, self-assembled monolayers, which are ordered arrays of organic molecules, have been utilized as interfacial layers in PSCs, in order to improve their efficiency and stability [91].

Another important issue faced in the commercialization of PSCs is the presence of lead in the absorber of most perovskite solar cells. Lead is a material with widely known environmental and health impacts. Lead has high toxicity and is hazardous both for the environment and human health, which has led to its gradual elimination from most devices and components, such as batteries. A number of research groups are currently focused in discovering successful alternatives to lead in perovskite solar cells. Lead-free PSCs are being developed by substituting lead with another element that has lower toxicity. Suitable replacements for lead in PSCs need to meet a number of criteria, such as the crystal structure and the quantum mechanical properties of the materials considered. The aim is to develop environmentally friendly solar cells with similar efficiency and stability as lead-based PSCs. A number of materials, such as transition metals, alkaline-earth metals, and rare-earth ions, have been investigated, with limited success so far. Various divalent metal cations have also been tested for use in PSCs, the most successful of which have been found to be $\mathrm{Ba}^{2+}, \mathrm{Ca}^{2+}$, and $\mathrm{Sr}^{2+}$ [92]. Strontium in particular has an ionic radius similar to that of lead, and preliminary experiments have shown that the compound resulting from the exchange of $\mathrm{Pb}$ with $\mathrm{Sr}$ $\left(\mathrm{CH}_{3} \mathrm{NH}_{3} \mathrm{SrI}_{3}\right)$ has similar crystal structure and bonding patterns to lead-based compounds [93]. Double perovskites have also been shown to have considerable potential for developing lead-free solar cells. Compounds such as 
TABLE 3: State-of-the-art materials, processes, and methods used for the development of PSCs.

\begin{tabular}{|c|c|c|c|}
\hline Photoanodes & Hole-transporting layer and interfaces & Device architecture & Improved stability \\
\hline $\begin{array}{l}\text { Improved morphology: precursor } \\
\text { solution aging, film annealing, and } \\
\text { incorporation of additives }\end{array}$ & $\begin{array}{l}\text { Organic hole-transporting layer (such } \\
\text { as carbon and spiro-MeOTAD) }\end{array}$ & $\begin{array}{l}\text { Single-junction } \\
\text { perovskite solar cells }\end{array}$ & $\begin{array}{c}\text { Mixed-cation systems (e.g., Rb and } \\
\mathrm{Cs} \text { ), or mixed-halide and mixed- } \\
\text { cation systems, retain 92\% of PCE } \\
\text { after } 1000 \mathrm{~h}\end{array}$ \\
\hline $\begin{array}{l}\text { Optimization of absorption layer } \\
\text { crystallinity and film uniformity }\end{array}$ & $\begin{array}{l}\text { Inorganic p-type semiconductor } \\
\text { materials, e.g., CuI, } \mathrm{NiO}, \mathrm{CuSCN} \text {, and } \\
\mathrm{CuGaO}_{2} \text {, up to } 18.5 \% \mathrm{PCE}\end{array}$ & $\begin{array}{l}\text { Perovskite/CIGS } \\
\text { tandem cells: perovskite } \\
\text { top cell fabricated on } \\
\text { CIGS bottom cell } \\
\text { Up to } 24.2 \% \text { PCE }\end{array}$ & $\begin{array}{c}\text { Interfacial layers with } \mathrm{UV} \text {-stable } \\
\text { materials }\left(\mathrm{SnO}_{2} \text {, ammonium }\right. \\
\text { chloride) retain } 94 \% \text { of efficiency } \\
\text { after } 1000 \mathrm{~h}\end{array}$ \\
\hline $\begin{array}{l}\text { Lead-free PSCs: transition metals, } \\
\text { alkaline-earth metals, rare-earth } \\
\text { ions, and divalent metal cations } \\
\left(\mathrm{Ba}^{2+}, \mathrm{Ca}^{2+} \text {, and } \mathrm{Sr}^{2+}\right)\end{array}$ & $\begin{array}{l}\text { Interface engineering and } \\
\text { optimization (e.g., incorporation of } \\
\text { benzenethiol molecules for increased } \\
\text { charge transport)-20\% PCE }\end{array}$ & $\begin{array}{l}\text { Perovskite/Si tandem } \\
\text { cells: top perovskite cell } \\
\text { and bottom Si cell } \\
\text { Up to } 29.5 \% \text { PCE }\end{array}$ & $\begin{array}{c}\text { Use of self-assembled monolayers } \\
\text { as interfacial layers }\end{array}$ \\
\hline $\begin{array}{l}\text { Double lead-free perovskites } \\
\left(\mathrm{Cs}_{2} \mathrm{AgSbI}_{6}, \mathrm{Cs}_{2} \mathrm{BiAuBr}_{6} \text {, and }\right. \\
\left.\mathrm{Cs}_{2} \mathrm{BiCuI}_{6}\right)\end{array}$ & $\begin{array}{l}\text { Energy level modification by } \\
\text { introducing an interfacial layer, such } \\
\text { as poly(ethylene oxide) }\end{array}$ & $\begin{array}{l}\text { Mechanically stacked } \\
\text { and monolithic tandem } \\
\text { device architectures }\end{array}$ & $\begin{array}{l}\text { Encapsulation: glass film/epoxy } \\
\text { resin, polymer sealants } \\
\text { (polyethylene terephthalate), and } \\
\text { lifetime }>10,000 \mathrm{~h}\end{array}$ \\
\hline
\end{tabular}

$\mathrm{Cs}_{2} \mathrm{AgSbI}_{6}, \mathrm{Cs}_{2} \mathrm{BiAuBr}_{6}$, and $\mathrm{Cs}_{2} \mathrm{BiCuI}_{6}$ have long recombination lifetime and optimum bandgap and have been reported to exhibit adequate stability even at high temperatures $[94,95]$. So far, the successful replacement of lead in PSCs has been rather limited, and future efforts are required in this area, in order to develop efficient and stable lead-free PSCs. Efforts to reduce the content of lead in PSCs rather than completely eliminating it have been more successful. Zhu et al. reported a power conversion efficiency of $15.20 \%$ for PSCs containing an alloy of $\mathrm{Sn}$ and $\mathrm{Pb}$ in the absorbing layer, developed from a solution in DMSO and DMF [96].

Table 3 summarizes some of the main materials, components, and techniques used for the development of novel single-junction perovskite and tandem perovskite cells with enhanced device performance.

3.3. Organic Solar Cells. For several years, research on OPVs was focused mainly on the design of low bandgap materials with optimum solar spectrum absorption in order to increase the PCEs of OPV cells $[97,98]$. Recent progress in OPVs is dominated by the development of low bandgap nonfullerene polymer acceptors (NFAs) [99-101]. Nonfullerene acceptors tend to exhibit high tunability in terms of their absorption spectra and electron energy levels, which allows for increased optimization of the resulting solar cells. Most of the topperforming NFAs, such as IT-4F36, IEICO-4F37, and BTCIC13, contain fluorine or chlorine atoms, and PCEs of over $16 \%$ have been obtained with chlorinated NFA-based OPV cells. Cui et al. [102] used the chlorinated nonfullerene acceptor BTP-4Cl in a blend with PBDB-TF to develop OPVs of an inverted structure with PCEs in excess of $16 \%$. More recently, the same group synthesized new NFAs based on BTP-4Cl through side chain engineering. The new materials exhibited improved solubility, which allowed for efficient processing through blade coating techniques and exhibited efficiencies of over $15 \%$ in a blend with PBDB-TF [34]. Current research in the area of nonfullerene OPVs is focused mainly on the development and optimization of nonfullerene donor- acceptor pairs with matching properties to increase OPV performance. Examples of copolymers that have been used successfully as donors combined with nonfullerene acceptors in OPVs include PM6, P2F-EHp, D16, and PTQ10. Liu et al. recently used D16, which is based on a fused-ring thiolactone unit, as a donor in a blend with Y6 to develop OPVs with over $16 \%$ efficiency and D18 in a blend with Y6 to achieve efficiencies of over $18 \%$ [103].

The effect of blend morphology on device performance is another parameter that has been investigated extensively in recent years [104]. Vertical and lateral phase segregation between the p-type and n-type semiconducting polymers in the blend has been shown to affect charge transport within the active layer [105]. Recent studies have been aimed at improving device performance by manipulating vertical phase segregation through the introduction of various interfacial layers. The addition of interlayers, especially between the active layer of the OPVs and the hole-transporting layer, has been shown to improve energy level alignment and facilitate charge transfer throughout the device. Cao et al. [106] used PBDTTPD-COOH as an interfacial modifier between the active layer and the hole-transporting layer, in PBDTTPD-, PCDTBT-, and PTB7-based OPVs. They concluded that the improvement in OPV performance through the addition of the interlayer was due to changes in energy level alignment and vertical phase segregation, as well as in blend composition at the PBDTTPD-COOH/donor interface. Inorganic semiconductors, such as $\mathrm{TiO}_{2}$ and $\mathrm{ZnO}$, have also been used as interlayers to improve charge transfer and collection and prevent hole formation in OPVs. Liu et al. [107] used Al-doped $\mathrm{ZnO}$ layers to create a semiconductormetal nanojunction in $\mathrm{PC}_{71} \mathrm{BM}$-based OPVs. The improved electron extraction and transport resulting from the addition of the interlayer led to an increase in efficiency from $7.89 \%$ to $9.81 \%$. Another class of materials that can be used as interlayers in OPVs is conjugated polyelectrolytes. These are composed of side chains with ionic functional groups and conjugated backbones and have improved hole 
transport and collection properties that can help boost device performance [108].

Research on small-molecule organic solar cells has also gained traction in recent years. One of the disadvantages of typical polymer-based OPVs is their relatively poor reproducibility, which hinders scalability, and is one of the main obstacles towards their commercialization. Small-molecule OPVs are a promising technology, due to their well-defined molecular structures and relatively high reproducibility compared to polymer OPVs [109]. On the other hand, smallmolecule devices tend to have lower PCEs than their polymer counterparts and are usually developed through highvacuum processes, which are not as cost-effective as solution processes that are available for polymeric materials. Recently, a number of breakthroughs in the area of small-molecule OPVs have led to a considerable increase in their efficiency, with PCEs in excess of 15\% reported and certified [110]. Most research efforts in this area are directed towards synthesizing new donor and acceptor small-molecule materials with optimized properties for use in OPVs. Liu et al. introduced fluorine atoms in small-molecule donors to achieve increased high open-circuit voltage in OPVs with the polymer $\mathrm{F}-2 \mathrm{Cl}$ used as an acceptor [111]. Qiu et al. synthesized new donor materials and used side chain engineering of these materials to optimize active layer morphology in a blend with Y6, resulting in efficiencies of over 14\% [112]. Similarly, Zhou et al. [113] synthesized a new small-molecule donor material and used a narrow bandgap small-molecule material as an acceptor, to achieve efficiencies over $14 \%$. The increased power conversion efficiencies achieved in this study were attributed to the optimization of the hierarchical morphologies of the donor and acceptor materials. Recently, $\mathrm{Hu}$ et al. developed all-small-molecule OPVs with PCEs in excess of $15 \%$. They used fullerene derivatives as additives in a BTRCl:Y6 active layer, which resulted in decreased electron recombination and high device fill factor [114].

Another area of increased interest in recent years is the development of ternary organic solar cells. In ternary OPVs, three organic semiconductors are used in the active layer, instead of two. The motivation behind introducing another semiconducting polymer in the device is to improve light absorption in the cell [115]. Ternary cells can be designed with complementary absorption bands to maximise the range of the solar spectrum that the cell absorbs and enhance its power conversion efficiency. In addition, the correlation between the energy levels of the three components of the ternary cells plays a crucial role in the development and optimization of these cells [116]. Good energy level alignment between the components of the ternary cells leads to increased charge transport and collection and thus improved device efficiency. Currently, research efforts are focused primarily on the synthesis and optimization of new donor and acceptor materials with synergetic properties that are suitable for ternary OPVs, in terms of their absorption, energy levels, and compatibility [117]. Ternary OPVs are ideally applicable in NFA cells, achieving efficiencies in excess of 14\% [118]. Ren et al. [119] developed a strategy based on the layer-bylayer sequential deposition of a polymer donor and two nonfullerene acceptors. Using the layer-by-layer method allowed for the optimization of the polymer blend and led to the formation of a network structure with increased charge generation, transport, and collection properties. Recently, Zhan et al. [120] reported a power conversion efficiency in excess of $17 \%$ for a ternary organic solar cell based on the polymer acceptor alloy Y6:BTP-M, with PM6 as the polymer donor. Similarly, An et al. [121] achieved power conversion efficiencies of over $17 \%$ for organic solar cells based on an alloy of the polymer acceptors MF1 and Y6 with PM6 as the polymer donor.

The main challenge towards the commercialization of both fullerene and NFA OPVs is scalability [122]. OPVs can be manufactured using more scalable techniques than spin coating, such as spray coating, blade coating, and inkjet printing. Large-area OPV cells developed using printing methods however have considerably lower PCEs than those of small-area spin-coated devices [34]. Another important issue is the long-term stability of organic solar cells, especially under outdoor weather conditions [123]. A large number of research efforts are currently focused on addressing scalability and stability issues to enable future commercialization of OPVs. In recent years, there has been increased interest in understanding the degradation mechanisms of OPVs and increasing their lifetime through a number of methods varying from the development of more stable polymer materials to the use of advanced packaging techniques. There are numerous causes for the degradation of solar cells, especially under environmental conditions. The fundamental materials of these cells tend to have low resistance to oxygen, moisture, high temperatures, illumination, etc., which lead to their rapid deterioration [2]. The most important amongst these reasons is considered to be the photodegradation of the active layer polymers, through exposure to extensive illumination.

A number of strategies are investigated in order to improve the stability and overall lifetime of organic solar cells, ranging from encapsulation of the device to the development of novel materials and processes. One of the most effective methods of encapsulation is to encase the device between glass plates and seal them using an epoxy resin [124]. Peters et al. achieved an overall lifetime of 7 years under illumination, for a PCDTBT:PC ${ }_{71} \mathrm{BM}$ cell encased in glass containing a desiccant layer and sealed with an epoxy resin [125]. This method of encapsulation however has the obvious disadvantage of negating the flexibility of OPVs, which is one of the major advantages of this technology. For that reason, a number of flexible polymer sealants have been developed in recent years to increase the stability of OPVs. Sapkota et al. developed completely flexible devices that retained over $95 \%$ of their original efficiency, after $1000 \mathrm{~h}$ under a damp heat test [126].

A number of materials and device processes have also been developed in order to increase the stability and lifetime of organic solar cells. Common methods to increase device stability include synthesizing novel materials for the active and the hole-transporting layer, as well as optimising the morphology of the active blend. Notably, Lee et al. recently developed OPVs with a $\mathrm{MoO}_{3}$ hole-transporting layer [127]. These devices exhibited excellent thermal stability at high temperatures in the range of 300-420 K, with PCEs 
TABLE 4: Summary of materials, processes, and methods used for the development of state-of-the-art OSCs.

\begin{tabular}{|c|c|c|c|}
\hline $\begin{array}{l}\text { Nonfullerene } \\
\text { acceptors (NFAs) }\end{array}$ & $\begin{array}{l}\text { NFAs with tunable absorption } \\
\text { spectra and electron energy levels }\end{array}$ & $\begin{array}{l}\text { NFAs with fluorine or chlorine atoms } \\
\text { (IT-4F36, IEICO-4F37, and } \\
\text { BT-CIC13), >16\% PCE }\end{array}$ & $\begin{array}{l}\text { Development of donors with } \\
\text { matching properties to NFAs } \\
\text { (e.g., PM6, P2F-EHp, D16, } \\
\text { and PTQ10), >18\% PCE }\end{array}$ \\
\hline Interfacial layers & $\begin{array}{c}\text { Interfacial layers } \\
\text { (e.g., PBDTTPD-COOH) optimize } \\
\text { vertical phase segregation }\end{array}$ & $\begin{array}{c}\text { Inorganic semiconductor } \\
\text { interlayers, such as } \\
\mathrm{TiO}_{2} \text { and } \mathrm{ZnO}>9 \% \mathrm{PCE}\end{array}$ & $\begin{array}{l}\text { Polyelectrolytes with side chains } \\
\text { of ionic functional groups } \\
\text { and conjugated backbones }\end{array}$ \\
\hline $\begin{array}{l}\text { Small-molecule } \\
\text { organic solar cells }\end{array}$ & $\begin{array}{l}\text { Small-molecule OPVs have } \\
\text { well-defined molecular } \\
\text { structures and high } \\
\text { reproducibility }\end{array}$ & $\begin{array}{l}\text { Synthesis of new donor and } \\
\text { acceptor small-molecule } \\
\text { materials }>15 \% \text { PCE }\end{array}$ & $\begin{array}{l}\text { All-small-molecule OPVs with } \\
\text { PCEs higher than } 15 \% \text { have } \\
\text { been developed }\end{array}$ \\
\hline Ternary OPVs & $\begin{array}{c}\text { Active layer with } 3 \text { organic } \\
\text { semiconductors to improve } \\
\text { light absorption }\end{array}$ & $\begin{array}{l}\text { Synthesis of novel donor and } \\
\text { acceptor materials with } \\
\text { synergetic properties }\end{array}$ & $\begin{array}{l}\text { Efficiencies of over } 17 \% \text { with } \\
\text { Y6:BTP-M/PM6 and } \\
\text { MF1:Y6/PM6 ternary OPVs }\end{array}$ \\
\hline $\begin{array}{l}\text { Manufacturing } \\
\text { techniques } \\
\text { and scalability }\end{array}$ & $\begin{array}{l}\text { Spin coating for high-efficiency, } \\
\text { small-area OPVs }\end{array}$ & Spray coating, blade coating & $\begin{array}{l}\text { Inkjet printing for } \\
\text { large-area OPVs }\end{array}$ \\
\hline $\begin{array}{l}\text { Stability and } \\
\text { lifetime }\end{array}$ & $\begin{array}{l}\text { Encapsulation in glass sealed } \\
\text { with epoxy resin results } \\
\text { in lifetime }>7 \text { years } \\
\text { under illumination }\end{array}$ & $\begin{array}{l}\text { OPVs with polymer sealants } \\
\text { retain }>95 \% \text { efficiency } \\
\text { after } 1000 \mathrm{~h} \text { under a } \\
\text { damp heat test }\end{array}$ & $\begin{array}{c}\text { Ternary OPVs with high } \\
\text { thermal stability retain } 98 \% \\
\text { of efficiency, after } 300 \mathrm{~h} \\
\text { of heating at } 65^{\circ}\end{array}$ \\
\hline
\end{tabular}

dropping at a reduced rate of $0.13 \% /{ }^{\circ} \mathrm{C}$ compared to $0.20 \% /{ }^{\circ} \mathrm{C}$ for cells with PEDOT:PSS as the hole-extracting layer. Employing an inverted device geometry has also been used extensively to increase device lifetime, since this structure tends to have higher stability by preventing the reaction between the active layer polymer and the metal electrode [128]. Ternary solar cells also tend to be more versatile and tunable, through the introduction of a third component in the active blend [129]. A number of research efforts focus on increasing the stability of ternary OPVs through the careful selection and optimization of appropriate materials in ternary devices. Recently, Liu et al. reported an $8.5 \%$ efficiency for a ternary device based on naphthalene di-imide polymer acceptor, in a blend with the polymer donors PBDT-TAZ and PTB7-Th [130]. This device exhibited high thermal stability, retaining $98 \%$ of its efficiency, after $300 \mathrm{~h}$ of heating at $65^{\circ}$. One other promising direction towards improving the stability and overall lifetime of organic solar cells is the use of the aforementioned nonfullerene acceptors. These materials have highly tunable properties and have been shown to have increased thermal and photochemical stability, resulting in improved device lifetimes compared to fullerene-based OPVs [122].

Table 4 summarizes some of the main materials, components, and techniques used for the development of novel organic solar cells.

\section{Sustainable Applications}

4.1. Dye-Sensitized Solar Cells. Dye-sensitized solar cells exhibit many unique features that make this technology highly appealing for sustainable solar energy applications. These cells can be fabricated using low-cost production processes and materials and are compatible with roll-to-roll printing techniques [39]. Large-area devices can be installed on flexible substrates, such as fabric or paper, opening the way to applications in the field of wearable electronics. The resulting flexible solar cells have a variety of potential applications such as in baggage, gears, or wearables. The military has shown interest in this technology for equipping tents and fabrics with flexible, lightweight DSSCs, which could power and recharge portable electrical devices [40].

In addition, DSSCs exhibit high performance in low-light conditions, including indoor lighting, and can thus be used for interior applications, as, for example, for powering small home electronic devices. The high efficiency of DSSCs under weak-light operating conditions makes this technology promising for several marketable applications, such as indoor light-harvesting devices, portable electronics, and even the automobile industry. Small indoor electronic devices with low power requirements can be powered by their own built-in solar cells, providing systems with a high degree of autonomous function and sustainability [131]. Figure 6 shows examples of DSSC applications. Another potential application of emerging photovoltaic technologies is in various integrated electronics, such as batteries, supercapacitors, or fuel cells, with an integrated solar cell that provides electrical energy [132]. Autonomous devices, which are powered by their own flexible, lightweight solar cells, can be used in remote regions not connected to the grid or for military applications. For example, small PV units can be integrated to rechargeable batteries that store the energy produced by the solar cells, in order to provide a portable power system [133]. Several studies have demonstrated the use of Libased batteries to successfully build a power pack with an incorporated DSSC module [134, 135]. Similarly, DSSCs have been integrated to supercapacitors, creating a fiber-like device that can achieve photoelectric conversion and energy storage at the same time and can be used in textiles and other lightweight applications [136]. Yang et al. [137] developed a 


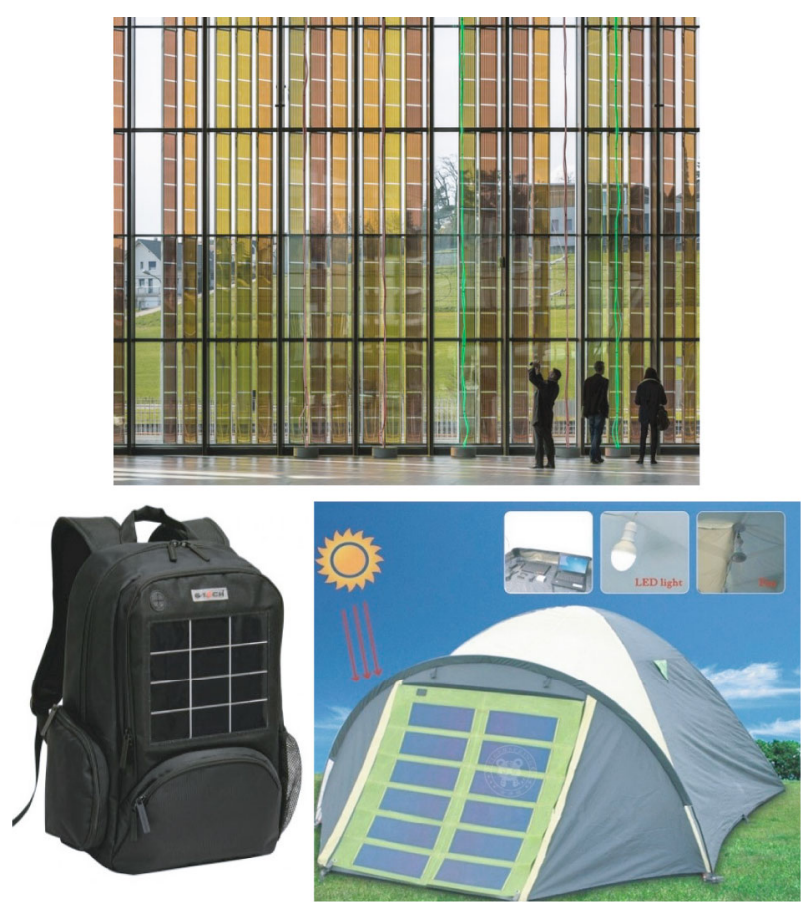

FIGURE 6: Examples of applications for dye-sensitized solar cells and modules [40].

stand-alone self-powered system comprised of a solid-state supercapacitor, four series-connected DSSCs, and a LED light. The system successfully lit a red LED light for over 30 minutes after being charged for only 2 minutes.

Due to their structural design and different colour dyes, DSSCs are semitransparent and can be produced in a wide array of colours. These features, combined with the aforementioned flexibility, make them compatible with a variety of architectural elements and provide unique applications in the field of building-integrated photovoltaics [41]. However, further research is required in order for this technology to become competitive for building-integrated applications. The low stability and lifetime of these devices hinder their use for large-scale architectural applications. Novel, solidstate electrolytes need to be developed in order to produce DSSCs with high stability and efficiency. In addition, the relatively low efficiency of DSSCs restricts their commercialization to niche technologies such as portable and disposable electronics. Further optimization of this technology is required to achieve efficiencies near $20 \%$ in order for DSSCs to become competitive for large-scale market commercialization.

4.2. Perovskite Solar Cells. Perovskite solar cells have become one of the most promising solar cell technologies due to their simple fabrication process and high PCEs, with recorded efficiencies of over 25\% [5]. The production process of PSCs is relatively simple, and the materials used are cheap and available in large quantities. Since perovskite cells are less costly to produce than their silicon counterparts, manufacturing them translates into considerably reduced energy consumption and lower production costs, which makes them a very attractive option for sustainable solar energy applications. In addi- tion, PSCs are lightweight and ultrathin and can be produced in different colours [45]. There is also the option of using various substrate surfaces, such as films or textiles, for the production of flexible solar cells, offering even more opportunities for specialized applications. Perovskite cells can generate energy from artificial light and are efficient even at low-scattered light, which means that they can harvest solar energy in shadowed areas or cloudy conditions and at nonvertical angles. This advantage over silicon cells, together with their lightweight, makes it possible to mount them even on vertical facade elements, thus making building integration of PSCs one of the most promising options for sustainable energy in buildings [75]. Semitransparent perovskite solar cells are especially attractive for building-integrated applications, as they offer a number of aesthetic architectural options [138]. Semitransparent PSCs can be used to cover the surface of buildings, windows, and roofs, providing an additional source of energy to the building. Their application in the windows of buildings or vehicles has been studied extensively in recent years. The absorption spectrum of PSCs can be tuned to the near-infrared or ultraviolet regions in order to increase their transparency. This offers the added benefits of protecting the building or vehicle interior from the heating effects of infrared radiation and the harmful effects of ultraviolet radiation [139].

Another promising application for PSCs would be in tandem device architectures. As discussed in Section 3.2, perovskite cell structures can be combined with another absorber material to produce high-efficiency devices. Since perovskite materials have tunable bandgaps, they can be designed to complement the absorption of other solar cells, such as $\mathrm{Si}$ or CIGS, thus increasing device efficiency considerably, while effectively reducing the associated cost per watt peak of the modules [132].

One issue that needs to be addressed for commercial large-scale PSC applications is the scalability of the devices. Large-scale devices need to be produced with high efficiency and reproducible processes before this technology can be used for large-area applications, such as building-integrated photovoltaics. Even though PSCs can be produced by relatively simple printing and coating techniques, large-scale devices produced to date have issues in uniformity and reproducibility, resulting in considerably lower efficiencies than small-area cells.

4.3. Organic Solar Cells. The low-cost manufacturing processing that is used for their production is a strong advantage of OPVs that is expected to make this technology competitive with conventional energy sources in certain markets. Other advantages of organic photovoltaics include their low weight and environmentally friendly degradability, which offer opportunities for new solar cell applications. Another important characteristic of OPVs is that printing and coating manufacturing techniques can be entirely conducted on flexible substrates [31], enabling the production of flexible devices that are suitable for a wider range of applications than conventional nonflexible photovoltaics.

The special properties of OPVs make them suitable for a wide range of sustainable solar energy applications, such as 


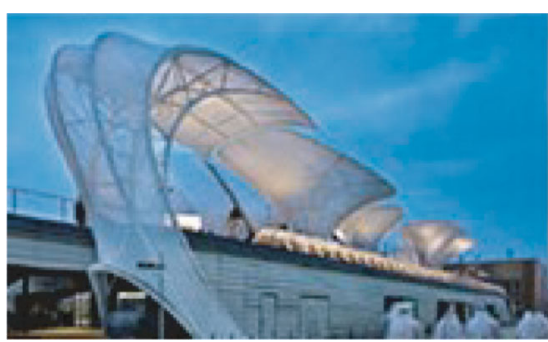

(a)

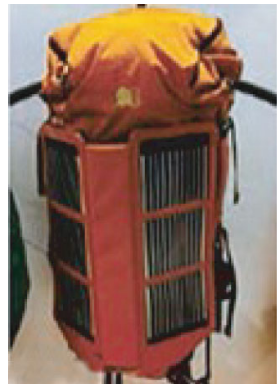

(c)

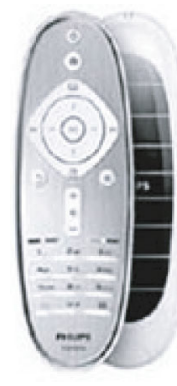

(d)

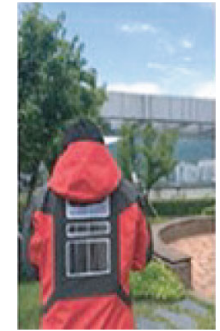

(b)

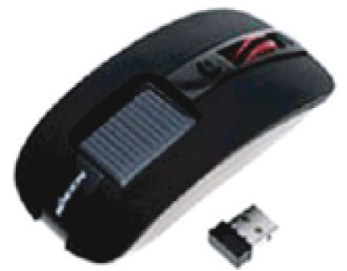

(e)

FIGURE 7: Examples of applications of OPVs: (a) building-integrated photovoltaics, (b) jacket with an incorporated OPV module, (c) backpack, (d) remote control, and (e) solar computer mouse [99].

TABLE 5: Summary of sustainable energy applications for DSSCs, PSCs, and OPVs.

\begin{tabular}{lcc}
\hline DSSC & PSC & OPV \\
\hline $\begin{array}{l}\text { Remote regions not connected to the grid } \\
\text { Wearable electronics: clothes, backpacks, }\end{array}$ & Multicoloured, semitransparent & Flexible devices, printable solar cells \\
baggage, and gears & Flexible solar cells on films or textiles & Fabrics, wearables: clothes \\
Military applications: tents and fabrics that & Building-integrated solar cells: & Building-integrated solar cells: \\
power portable electrical devices & facades and roofs & windows and facades \\
$\begin{array}{l}\text { Indoor light-harvesting devices: } \\
\text { small, indoor electronic devices with }\end{array}$ & $\begin{array}{c}\text { Semitransparent: applications } \\
\text { low power requirements }\end{array}$ & in the windows of buildings \\
Integrated electronics: fuel cells, & or vehicles & Indoor light applications: \\
batteries, and supercapacitors & Tandem device architectures: & small indoor devices \\
\hline
\end{tabular}

building-integrated photovoltaics (Figure 7(a)), wearables (Figures 7(b) and 7(c)), and powering small indoor electronic devices (Figures 7(d) and 7(e)). Since OPVs are thin and flexible, they can be incorporated into a variety of substrates and building materials including standard lamination on glass [100]. In addition, OPV modules do not exhibit a drop in performance caused by typical outdoor conditions such as diffuse light and high temperatures and can be developed in different shapes and degrees of transparency making them ideal for integration in sustainable energy buildings [140]. Recently, OPVs were used to fabricate a $>250 \mathrm{~m}^{2}$ flexible power system reaching an average performance of $\sim 5 \%$ (PCE) in a semitransparent configuration (Figure $7(\mathrm{a})$ ).

The optical absorption of OPVs can be tuned to be compatible with the narrow emission spectra and lower light intensity of the commonly used indoor light sources [141]. This property, along with their lightweight, flexibility, and colouration, makes them ideal for indoor applications. Recently, Ding et al. designed all-polymer solar cells for indoor applications with high open-circuit voltage of $1.16 \mathrm{~V}$ and PCE of $27.4 \%$ under fluorescent lamp illumination [142]. Cui et al. developed an organic photovoltaic module for indoor applications with an area of $1 \mathrm{~cm}^{2}$ that exhibited a power conversion efficiency of $22 \%$ under 1000 lux LED illumination [143]. More recently, Bai et al. developed a ternary OPV for indoor light applications, based on the benzotriazole donor J52-F, the chlorinated donor PM7, and the acceptor BTA3. The device yielded a power conversion efficiency in excess of $20 \%$ under 300 lux LED illumination with a temperature of $3000 \mathrm{~K}$ [144].

Table 5 shows a comparative summary of the main sustainable energy applications for DSSCs, PSCs, and OPVs.

\section{Conclusions}

Rising global demands for energy, combined with the rapid depletion of fossil fuels, has led to increased interest in renewable energy sources over the past decades. From a 
purely economic standpoint however, silicon solar cells are not yet competitive with fossil fuel sources. Further reduction in the cost of solar energy is required to increase the market share of this technology. This reduction in the cost of solar energy can be achieved through the development of new solar cell materials and device concepts. A number of alternatives to silicon-based cells are being investigated, aiming at the development of photovoltaic devices with relatively high conversion efficiency at lower costs.

Third-generation photovoltaic technologies such as dyesensitized solar cells, organic solar cells, and perovskite solar cells have emerged in recent years and have shown potential for large-scale commercialization. These promising solar cell technologies are developed using low-cost production processes, they are less sensitive to ambient temperature changes, and they have good performance in low-light conditions and can be installed on flexible substrates. Their properties make them ideal for many sustainable solar energy applications, ranging from small-scale self-powered electronic devices, such as electronic calculators, to large-scale, energetically self-sufficient buildings.

Dye-sensitized solar cells are best suited to niche applications, such as disposable electronics, due to their low cost and also to their relatively low stability. Organic solar cells can be especially used for the production of flexible solar cells using simple printing roll-to-roll processes. Perovskite solar cells are widely considered the most promising new solar cell technology. Their PCEs can rival those of silicon-based solar cells, at considerably lower cost, and they are suitable for numerous sustainable solar energy applications. They can also be used in tandem with other solar cell technologies, such as $\mathrm{Si}$ or CIGS, resulting in high-efficiency, cost-effective solar cell devices.

These emerging solar cell technologies however are still not commercially available in large volumes. Disadvantages such as the relatively low efficiency and stability of these cells compared to silicon-based solar cells pose a hindrance to their commercialization. Current research efforts are focused on overcoming these obstacles through the development of novel materials, processing techniques, and device architectures. The outcome of these research efforts is expected to unlock the potential of emerging solar cell technologies and lead to their future commercialization.

\section{Data Availability}

No data were used to support this study.

\section{Conflicts of Interest}

The author declares that she has no conflicts of interest.

\section{References}

[1] J. Gong, K. Sumathy, Q. Qiao, and Z. Zhou, "Review on dyesensitized solar cells (DSSCs): Advanced techniques and research trends," Renewable and Sustainable Energy Reviews, vol. 68, pp. 234-246, 2017.
[2] M. Giannouli, V. M. Drakonakis, A. Savva, P. Eleftheriou, G. Florides, and S. A. Choulis, "Methods for improving the lifetime performance of organic photovoltaics with lowcosting encapsulation," ChemPhysChem, vol. 16, no. 6, pp. 1134-1154, 2015.

[3] M. Sessolo and H. J. Bolink, "Perovskite solar cells join the major league," Science, vol. 350, no. 6263, p. 917, 2015.

[4] G. D. Sharma, P. A. Angaridis, S. Pipou et al., "Efficient cosensitization of dye-sensitized solar cells by novel porphyrin/triazine dye and tertiary aryl-amine organic dye," Organic Electronics, vol. 25, pp. 295-307, 2015.

[5] National Renewable Energy Laboratory (NREL), Golden, CO, 2020January 2021, https://www.nrel.gov/pv/assets/ pdfs/best-research-cell-efficiencies.20201228.pdf.

[6] O. Haillant, "Accelerated weathering testing principles to estimate the service life of organic PV modules," Solar Energy Materials and Solar Cells, vol. 95, no. 5, pp. 1284-1292, 2011.

[7] S. Prasanthkumar and L. Giribabu, "Recent advances in perovskite-based solar cells," Current Science, vol. 111, no. 7, pp. 1173-1181, 2016.

[8] B. O'Regan and M. Grätzel, "A low-cost, high-efficiency solar cell based on dye-sensitized colloidal $\mathrm{TiO}_{2}$ films," Nature, vol. 353, no. 6346, pp. 737-740, 1991.

[9] M. A. Green, E. D. Dunlop, J. Hohl-Ebinger, M. Yoshita, N. Kopidakis, and A. W. Y. Ho-Baillie, "Solar cell efficiency tables (Version 55)," Progress in Photovoltaics: Results and Applications, vol. 28, no. 1, pp. 3-15, 2020.

[10] A. Yella, H.-W. Lee, H. N. Tsao et al., "Porphyrin-Sensitized Solar Cells with Cobalt (II/III)-Based Redox Electrolyte Exceed 12 Percent Efficiency," Science, vol. 334, no. 6056, pp. 629-634, 2011.

[11] S. Shalini, R. Balasundaraprabhu, T. S. Kumar, N. Prabavathy, S. Senthilarasu, and S. Prasanna, "Status and outlook of sensitizers/dyes used in dye sensitized solar cells (DSSC): a review," International Journal of Energy Research, vol. 40, no. 10, pp. 1303-1320, 2016.

[12] M. Giannouli and M. Fakis, "Interfacial electron transfer dynamics and photovoltaic performance of $\mathrm{TiO}_{2}$ and $\mathrm{ZnO}$ solar cells sensitized with Coumarin 343," Journal of Photochemistry and Photobiology A: Chemistry, vol. 226, no. 1, pp. 42-50, 2011.

[13] M. Giannouli and F. Spiliopoulou, "Effects of the morphology of nanostructured $\mathrm{ZnO}$ films on the efficiency of dyesensitized solar cells," Renewable Energy, vol. 41, pp. 115122, 2012.

[14] M. Ye, X. Wen, M. Wang et al., "Recent advances in dyesensitized solar cells: from photoanodes, sensitizers and electrolytes to counter electrodes," Materials Today, vol. 18, no. 3, pp. 155-162, 2015.

[15] H. Zhang, Y. Wang, D. Yang et al., "Directly Hydrothermal Growth of Single Crystal Nb3O7(OH) Nanorod Film for High Performance Dye-Sensitized Solar Cells," Advanced Materials, vol. 24, no. 12, pp. 1598-1603, 2012.

[16] M. Ye, X. Xin, C. Lin, and Z. Lin, "High Efficiency DyeSensitized Solar Cells Based on Hierarchically Structured Nanotubes," Nanoletters, vol. 11, no. 8, pp. 3214-3220, 2011.

[17] Q. Yu, Y. Wang, Z. Yi et al., "High-Efficiency Dye-Sensitized Solar Cells: The Influence of Lithium Ions on Exciton Dissociation, Charge Recombination, and Surface States," ACS Nano, vol. 4, no. 10, pp. 6032-6038, 2010. 
[18] Z. Song, S. C. Watthage, A. B. Phillips, and M. J. Heben, "Pathways toward high-performance perovskite solar cells: review of recent advances in organo-metal halide perovskites for photovoltaic applications," Journal of Photonics for Energy, vol. 6, no. 2, article 022001, 2016.

[19] M. Grätzel, "The light and shade of perovskite solar cells," Nature Materials, vol. 13, no. 9, pp. 838-842, 2014.

[20] C. C. Stoumpos and M. G. Kanatzidis, "Halide Perovskites: Poor Man's High-Performance Semiconductors," Advanced Materials, vol. 28, no. 28, pp. 5778-5793, 2016.

[21] A. Kojima, K. Teshima, Y. Shirai, and T. Miyasaka, "Organometal Halide Perovskites as Visible-Light Sensitizers for Photovoltaic Cells," Journal of the American Chemical Society, vol. 131, no. 17, pp. 6050-6051, 2009.

[22] J.-H. Im, C.-R. Lee, J.-K. Lee, S.-W. Park, and N.-G. Park, "6.5\% efficient perovskite quantum-dot-sensitized solar cell," Nanoscale, vol. 3, no. 10, pp. 4088-4093, 2011.

[23] H.-S. Kim, C.-R. Lee, J.-H. Im et al., "Lead Iodide Perovskite Sensitized All-Solid-State Submicron Thin Film Mesoscopic Solar Cell with Efficiency Exceeding 9\%," Scientific Reports, vol. 2, no. 1, p. 591, 2012.

[24] M. M. Lee, J. Teuscher, T. Miyasaka, T. N. Murakami, and H. J. Snaith, "Efficient Hybrid Solar Cells Based on MesoSuperstructured Organometal Halide Perovskites," Science, vol. 338, no. 6107, pp. 643-647, 2012.

[25] J. Burschka, N. Pellet, S.-J. Moon et al., "Sequential deposition as a route to high-performance perovskite-sensitized solar cells," Nature, vol. 499, no. 7458, pp. 316-319, 2013.

[26] M. Liu, M. B. Johnston, and H. J. Snaith, "Efficient planar heterojunction perovskite solar cells by vapour deposition," Nature, vol. 501, no. 7467, pp. 395-398, 2013.

[27] N. J. Jeon, J. H. Noh, Y. C. Kim, W. S. Yang, S. Ryu, and S. I. Seok, "Solvent engineering for high-performance inorganicorganic hybrid perovskite solar cells," Nature Materials, vol. 13, no. 9, pp. 897-903, 2014.

[28] H. Zhou, Q. Chen, G. Li et al., "Interface engineering of highly efficient perovskite solar cells," Science, vol. 345, no. 6196, pp. 542-546, 2014.

[29] M. Saliba, T. Matsui, J.-Y. Seo et al., "Cesium-containing triple cation perovskite solar cells: improved stability, reproducibility and high efficiency," Energy and Environtal Science, vol. 9, no. 6, pp. 1989-1997, 2016.

[30] F. C. Krebs, "Fabrication and processing of polymer solar cells: A review of printing and coating techniques," Solar Energy Materials and Solar Cells, vol. 93, no. 4, pp. 394412, 2009.

[31] F. C. Krebs, "All solution roll-to-roll processed polymer solar cells free from indium-tin-oxide and vacuum coating steps," Organic Electronics, vol. 10, no. 5, pp. 761-768, 2009.

[32] F. C. Krebs and K. Norrman, "Using light-induced thermocleavage in a roll-to-roll process for polymer solar cells," ACS Applied Materials and Interfaces, vol. 2, no. 3, pp. 877887, 2010.

[33] S. H. Park, A. Roy, S. Beaupre et al., "Bulk heterojunction solar cells with internal quantum efficiency approaching 100\%," Nature Photonics, vol. 3, no. 5, pp. 297-302, 2009.

[34] Y. Cui, H. Yao, L. Hong et al., "Organic photovoltaic cell with $17 \%$ efficiency and superior processability," National Science Review, vol. 7, no. 7, pp. 1239-1246, 2020.

[35] E. R. Rwenyagila, "A review of organic photovoltaic energy source and its technological designs," International Journal of Photoenergy, vol. 2017, Article ID 1656512, 12 pages, 2017.

[36] L. J. A. Koster, E. C. P. Smits, V. D. Mihailetchi, and P. W. Blom, "Device model for the operation of polymer/fullerene bulk heterojunction solar cells," Physical Review B, vol. 72, pp. 1-9, 2005.

[37] J. Yuan, J. Ouyang, V. Cimrová, M. Leclerc, A. Najari, and Y. Zou, "Development of quinoxaline-based polymers for photovoltaic applications," Journal of Materials Chemistry C, vol. 5, no. 8, pp. 1858-1879, 2017.

[38] G. Boschloo, "Improving the performance of dye-sensitized solar cells," Frontiers in Chemistry, vol. 7, p. 77, 2019.

[39] M. Giannouli, "Nanostructured $\mathrm{ZnO}, \mathrm{TiO} 2$, and Composite $\mathrm{ZnO} / \mathrm{TiO} 2$ Films for Application in Dye- Sensitized Solar Cells," International Journal of Photoenergy, vol. 2013, Article ID 612095, 8 pages, 2013.

[40] L. Calderone, Dye Sensitized Solar Cells Is the Future of Solar, 2020, https://www.altenergymag.com.

[41] M. Carella, F. Borbone, and R. Centore, "Research progress on photosensitizers for DSSC," Frontiers in Chemistry, vol. 11, 2018.

[42] S. Prasad, D. Devaraj, B. Rajender, S. Sunitha, and M. S. AlSalhi, "Fabrication, device performance, and MPPT for flexible dye-sensitized solar panel based on gel-polymer phthaloylchitosan based electrolyte and nanocluster $\mathrm{CoS}_{2}$ counter electrode," Materials Science for Energy Technologies, vol. 2, no. 2, pp. 319-328, 2019.

[43] M. Freitag, F. Giordano, W. X. Yang et al., "Copper phenanthroline as a fast and high-performance redox mediator for dye-sensitized solar cells," Journal of Physical Chemistry C, vol. 120, no. 18, pp. 9595-9603, 2016.

[44] X. Wang, S. Kulkarni, B. Ito et al., "Nanoclay Gelation Approach toward Improved Dye-Sensitized Solar Cell Efficiencies: An Investigation of Charge Transport and Shift in the $\mathrm{TiO}_{2}$ Conduction Band," ACS Applied Materials and Interfaces, vol. 5, no. 2, pp. 444-450, 2013.

[45] I. Chung, B. Lee, J. He, R. P. H. Chang, and M. G. Kanatzidis, "All-solid-state dye-sensitized solar cells with high efficiency," Nature, vol. 485, no. 7399, pp. 486-489, 2012.

[46] K. Sharma, V. Sharma, and S. S. Sharma, "Dye-sensitized solar cells: fundamentals and current status," Nanoscale Research Letters, vol. 13, no. 1, p. 381, 2018.

[47] D. Colonna, V. Capogna, A. Lembo, T. M. Brown, A. Reale, and A. Di Carlo, "Efficient Cosensitization Strategy for DyeSensitized Solar Cells," Applied Physics Express, vol. 5, no. 2, article 022303, 2012.

[48] J. Ji, H. Zhou, Y. K. Eom, C. H. Kim, and H. K. Kim, “14.2\% efficiency dye-sensitized solar cells by co-sensitizing novel thieno[3,2-b] indole-based organic dyes with a promising porphyrin sensitizer," Advanced Energy Materials, vol. 10, no. $15,2020$.

[49] P. Zuo, C. Li, Y. S. Wu et al., "Mechanism of squarylium cyanine and $\mathrm{Ru}(\mathrm{dcbpy})_{2}(\mathrm{NCS})_{2}$ co-sensitization of colloidal $\mathrm{TiO}_{2}$," Journal of Photochemistry and Photobiology A, vol. 183, no. 1-2, pp. 138-145, 2006.

[50] J. H. Yum, B. E. Hardin, S. J. Moon et al., "Panchromatic Response in Solid-State Dye-Sensitized Solar Cells Containing Phosphorescent Energy Relay Dyes," Molecular Solar Cells, vol. 48, no. 49, pp. 9277-9280, 2009.

[51] R. Ogura, S. Nakane, M. Morooka, M. Orihashi, Y. Suzuki, and K. Noda, "High-performance dye-sensitized solar cell 
with a multiple dye system," Applied Physics Letters, vol. 94, no. 7, article 073308, 2009.

[52] V. Saxena, P. Veerender, A. K. Chauhan, P. Jha, D. K. Aswal, and S. K. Gupta, "Efficiency enhancement in dye sensitized solar cells through co-sensitization of $\mathrm{TiO}_{2}$ nanocrystalline electrodes," Applied Physics Letters, vol. 100, no. 13, article 133303, 2012.

[53] S. Rani, P. K. Shishodia, and R. M. Mehra, "Development of a dye with broadband absorbance in visible spectrum for an efficient dye-sensitized solar cell," Journal of Renewable and Sustainable Energy, vol. 2, no. 4, article 043103, 2010.

[54] N. Shibayama, H. Ozawa, M. Abe, Y. Ooyama, and H. Arakawa, "A new cosensitization method using the Lewis acid sites of a $\mathrm{TiO}_{2}$ photoelectrode for dye-sensitized solar cells," Chemical Communications, vol. 50, no. 48, pp. 63986401, 2014.

[55] S. Fan, X. Lu, H. Sun, G. Zhou, J. Changc, and Z.-S. Wang, "Effect of the co-sensitization sequence on the performance of dye-sensitized solar cells with porphyrin and organic dyes," Physical Chemistry Chemical Physics, vol. 18, no. 2, pp. 932-938, 2016.

[56] M. Giannouli, G. Tziogkidou, and G. Leftheriotis, "Co-sensitization of $\mathrm{ZnO}$ solar cells by organic dyes," Journal of Renewable and Sustainable Energy, vol. 9, no. 1, article 013503, 2017.

[57] H. K. Jun, M. A. Careem, and A. K. Arof, "Plasmonic effects of quantum size gold nanoparticles on dye-sensitized solar cell," Materials Today: Proceedings, vol. 3, pp. S73-S79, 2016.

[58] N. A. Bakr, A. K. Ali, and S. M. Jassim, "Fabrication and efficiency enhancement of Z907 dye sensitized solar cell using gold nanoparticles," j adv phys, vol. 6, no. 3, pp. 370-374, 2017.

[59] Y. H. Sim, M. J. Yun, S. I. Cha, S. H. Seo, and D. Y. Lee, "Improvement in energy conversion efficiency by modification of photon distribution within the photoanode of dyesensitized solar cells," ACS Omega, vol. 3, pp. 698-705, 2018.

[60] M. Stolterfoht, M. Grischek, P. Caprioglio et al., "How To Quantify the Efficiency Potential of Neat Perovskite Films: Perovskite Semiconductors with an Implied Efficiency Exceeding 28\%," Advanced Materials, vol. 32, no. 17, article 2000080, 2020.

[61] D. Zhou, T. Zhou, Y. Tian, X. Zhu, and Y. Tu, "Perovskitebased solar cells: materials, methods, and future perspectives," Journal of Nanomaterials, vol. 2018, Article ID 8148072, 15 pages, 2018.

[62] P. Boonmongkolras, D. Kim, E. M. Alhabshi, I. Gereige, and B. Shin, "Understanding effects of precursor solution aging in triple cation lead perovskite," RSC Advances, vol. 8, no. 38, pp. 21551-21557, 2018.

[63] J. J. van Franeker, K. H. Hendriks, B. J. Bruijnaers, M. W. G. M. Verhoeven, M. M. Wienk, and R. A. J. Janssen, "Monitoring Thermal Annealing of Perovskite Solar Cells with In Situ Photoluminescence," Advanced Energy Materials, vol. 7, no. 7, article 1601822, 2017.

[64] D. Xin, S. Tie, X. Zheng, J. Zhu, and W.-H. Zhang, "Defect passivation through electrostatic interaction for high performance flexible perovskite solar cells," Journal of Energy Chemistry, vol. 46, pp. 173-177, 2020.

[65] N. Tailor, M. Abdi-Jalebi, V. Gupta et al., "Recent progress in morphology optimization in perovskite solar cell," Journal of Materials Chemistry A, vol. 8, no. 41, pp. 21356-21386, 2020.
[66] M. Feng, S. You, N. Cheng, and J. Du, "High quality perovskite film solar cell using methanol as additive with $19.5 \%$ power conversion efficiency," Electrochimica Acta, vol. 293, pp. 356-363, 2019.

[67] Z. Wu, Z. Liu, Z. Hu et al., "Highly Efficient and Stable Perovskite Solar Cells via Modification of Energy Levels at the Perovskite/Carbon Electrode Interface," Advanced Materials, vol. 31, no. 11, article e1804284, 2019.

[68] J. Lu, X. Lin, X. Jiao et al., "Interfacial benzenethiol modification facilitates charge transfer and improves stability of $\mathrm{cm}$ sized metal halide perovskite solar cells with up to $20 \%$ efficiency," Energy \& Environmental Science, vol. 11, no. 7, pp. 1880-1889, 2018.

[69] S. Seo, I. J. Park, M. Kim et al., "An ultra-thin, un-doped $\mathrm{NiO}$ hole transporting layer of highly efficient (16.4\%) organicinorganic hybrid perovskite solar cells," Nanoscale, vol. 8, no. 22, pp. 11403-11412, 2016.

[70] H. Zhang, H. Wang, W. Chen, and A. K.-Y. Jen, "CuGaO2: a promising inorganic hole-transporting material for highly efficient and stable perovskite solar cells," Advanced Materials, vol. 29, no. 8, article 1604984, 2017.

[71] F. Meillaud, A. Shah, C. Droz, E. Vallat-Sauvain, and C. Miazza, "Efficiency limits for single-junction and tandem solar cells," Solar Energy Materials and Solar Cells, vol. 90, no. 18-19, pp. 2952-2959, 2006.

[72] J.-W. Lee, D.-J. Seol, A.-N. Cho, and N.-G. Park, "High-Efficiency Perovskite Solar Cells Based on the Black Polymorph of $\mathrm{HC}(\mathrm{NH} 2) 2 \mathrm{PbI} 3$," Advanced Materials, vol. 26, no. 29, pp. 4991-4998, 2014.

[73] F. Zhang, S. Wang, Y. Xiao, and X. Li, "Improvement in photovoltaic performance of perovskite solar cells by interface modification and co-sensitization with novel asymmetry 7coumarinoxy-4-methyltetrasubstituted metallophthalocyanines," Synthetic Metals, vol. 220, pp. 187-193, 2016.

[74] N. Balachandran, T. M. Robert, D. Mathew, and J. Cyriac, "Co-sensitization of perovskite solar cells by organometallic compounds: mechanism and photovoltaic characterization," Proceedings of the 7th International Conference on Advances in Energy Research. Springer Proceedings in Energy, M. Bose and A. Modi, Eds., Springer, Singapore, 2021.

[75] M. Banavoth, Perovskite Solar Cells: Properties, Application and Efficiency, Nova Science Publishers, 2019.

[76] A. Roy, A. Ghosh, S. Bhandari, S. Sundaram, and T. K. Mallick, "Perovskite solar cells for BIPV application: a review," Buildings, vol. 10, no. 7, p. 129, 2020.

[77] T. Todorov, T. Gershon, O. Gunawan et al., "Monolithic perovskite-CIGS tandem solar cells via in situ band gap engineering," Advanced Energy Materials, vol. 5, p. 23, 2015.

[78] J. Park, J. H. Park, S. Ji, M. Park, J. Jang, and J. Kim, “A three-terminal monolithic perovskite/Si tandem solar cell characterization platform," Joule, vol. 3, no. 3, pp. 807818, 2019.

[79] M. I. Hossain, W. Qarony, S. Ma, L. Zeng, D. Knipp, and Y. H. Tsang, "Perovskite/silicon tandem solar cells: from detailed balance limit calculations to photon management," Nano-Micro Letters, vol. 11, no. 1, p. 58, 2019.

[80] H. Shen, D. Walter, Y. Wu et al., "Monolithic perovskite/Si tandem solar cells: pathways to over $30 \%$ efficiency," Advanced Energy Materials, vol. 10, p. 3, 2020.

[81] F. Fu, T. Feurer, T. Jäger et al., "Low-temperature-processed efficient semi-transparent planar perovskite solar cells for 
bifacial and tandem applications," Nature Communications, vol. 6, article 8932, 2015.

[82] Y. Hou, E. Aydin, M. De Bastiani et al., "Efficient tandem solar cells with solution-processed perovskite on textured crystalline silicon," Science, vol. 367, no. 6482, pp. 11351140, 2020.

[83] B. Conings, J. Drijkoningen, N. Gauquelin et al., "Intrinsic thermal instability of methylammonium lead trihalide perovskite," Advanced Energy Materials, vol. 5, no. 15, article 1500477, 2015.

[84] M. Saliba, T. Matsui, K. Domanski et al., "Incorporation of rubidium cations into perovskite solar cells improves photovoltaic performance," Science, vol. 354, no. 6309, pp. 206209, 2016.

[85] T. Matsui, T. Yamamoto, T. Nishihara et al., "Compositional Engineering for Thermally Stable, Highly Efficient Perovskite Solar Cells Exceeding 20\% Power Conversion Efficiency with $85{ }^{\circ} \mathrm{C} / 85 \% 1000$ h Stability," Advanced Materials, vol. 31, no. 10, article 1806823, 2019.

[86] J. Zhu, M. Tang, B. He et al., "Improved charge extraction through interface engineering for $10.12 \%$ efficiency and stable CsPbBr3perovskite solar cells," Journal of Materials Chemistry A, vol. 8, no. 40, pp. 20987-20997, 2020.

[87] J. A. Christians, P. Schulz, J. S. Tinkham et al., "Tailored interfaces of unencapsulated perovskite solar cells for $>1,000$ hour operational stability," Nature Energy, vol. 3, no. 1, pp. 68-74, 2018.

[88] S. A. Gevorgyan, M. V. Madsen, H. F. Dam et al., "Interlaboratory outdoor stability studies of flexible roll-to-roll coated organic photovoltaic modules: Stability over 10,000 h," Solar Energy Materials and Solar Cells, vol. 116, pp. 187-196, 2013.

[89] F. Bella, G. Griffini, J. Correa-Baena et al., "Improving efficiency and stability of perovskite solar cells with photocurable fluoropolymers," Science, vol. 354, no. 6309, pp. 203206, 2016.

[90] K. A. Bush, A. F. Palmstrom, J. Y. Zhengshan et al., "23.6\%efficient monolithic perovskite/silicon tandem solar cells with improved stability," Nature Energy, vol. 2, pp. 1-7, 2017.

[91] F. Ali, C. Roldán-Carmona, M. Sohail, and M. K. Nazeeruddin, "Applications of self-assembled monolayers for perovskite solar cells interface engineering to address efficiency and stability," Advanced Energy Materials, vol. 10, no. 48, article 2002989, 2020.

[92] M. Pazoki, T. J. Jacobsson, A. Hagfeldt, G. Boschloo, and T. Edvinsson, "Effect of metal cation replacement on the electronic structure of metalorganic halide perovskites: replacement of lead with alkaline-earth metals," Physical Review B: Condensed Matter and Materials Physics, vol. 93, pp. 144105-144110, 2016.

[93] T. J. Jacobsson, M. Pazoki, A. Hagfeldt, and T. Edvinsson, "Goldschmidt's rules and strontium replacement in lead halogen perovskite solar cells: theory and preliminary experiments on $\mathrm{CH} 3 \mathrm{NH}_{3} \mathrm{SrI}_{3}$," The Journal of Physical Chemistry C, vol. 119, pp. 25673-25683, 2015.

[94] G. Volonakis, M. R. Filip, A. A. Haghighirad et al., "Lead-free halide double perovskites via heterovalent substitution of noble metals," Journal of Physical Chemistry Letters, vol. 7, pp. 1254-1259, 2016.

[95] C. Wu, Q. Zhang, Y. Liu et al., “The Dawn of Lead-Free Perovskite Solar Cell: Highly Stable Double Perovskite
$\mathrm{Cs}_{2} \mathrm{AgBiBr}_{6}$ Film," Advancement of Science, vol. 5, article 1700759, 2018.

[96] H. L. Zhu, J. Xiao, J. Mao, H. Zhang, Y. Zhaoand, and W. C. H. Choy, "Controllable Crystallization of $\mathrm{CH}_{3} \mathrm{NH}_{3} \mathrm{Sn}_{0.25} \mathrm{~Pb}_{0.75} \mathrm{I}_{3}$ Perovskites for Hysteresis-Free Solar Cells with Efficiency Reaching 15.2\%," Advanced Functional Materials, vol. 27, no. 11, article 1605469, 2017.

[97] Z. Qiu, Z. Xu, N. Li et al., "Monolithic perovskite/Si tandem solar cells exceeding $22 \%$ efficiency via optimizing top cell absorber," Nano Energy, vol. 53, pp. 798-807, 2018.

[98] M. Jost, L. Kegelmann, L. Korte, and S. Albrecht, "Monolithic perovskite tandem solar cells: a review of the present status and advanced characterization methods toward 30\% efficiency," Advanced Energy Materials, vol. 10, no. 26, article 1904102, 2020.

[99] Q. Han, Y.-T. Hsieh, L. Meng et al., "High-performance perovskite/Cu(In, Ga)Se ${ }_{2}$ monolithic tandem solar cells," Science, vol. 361, pp. 904-908, 2018.

[100] G. Morse, R. Harding, N. Blouin et al., "Organic photovoltaic applications for IoT," Architecture, and Wearables, Material Matters, vol. 12, no. 3, 2017.

[101] J. Zhang, H. S. Tan, X. Guo, A. Facchetti, and H. Yan, "Material insights and challenges for non-fullerene organic solar cells based on small molecular acceptors," Nature Energy, vol. 3, no. 9, pp. 720-731, 2018.

[102] Y. Cui, H. Yao, J. Zhang et al., "Over 16\% efficiency organic photovoltaic cells enabled by a chlorinated acceptor with increased open-circuit voltages," Nature Communications, vol. 10, no. 1, article 2515, 2019.

[103] Q. Liu, Y. Jiang, K. Jin et al., "18\% efficiency organic solar cells," Science Bulletin, vol. 65, no. 4, pp. 272-275, 2020.

[104] G. Chidichimo and L. Filippelli, "Organic solar cells: problems and perspectives," International Journal of Photoenergy, vol. 2010, Article ID 123534, 11 pages, 2010.

[105] M. Campoy-Quiles, T. Ferenczi, T. Agostinelli et al., "Morphology evolution via self-organization and lateral and vertical diffusion in polymer/fullerene solar cell blends," Nature Materials, vol. 7, pp. 158-164, 2008.

[106] B. Cao, X. He, C. R. Fetterly, B. C. Olsen, E. J. Luber, and J. M. Buriak, "Role of interfacial layers in organic solar cells: energy level pinning versus phase segregation," ACS Applied Materials \& Interfaces, vol. 8, pp. 18238-18248, 2016.

[107] C. Liu, D. Zhang, Z. Li et al., "Decreased charge transport barrier and recombination of organic solar cells by constructing interfacial nanojunction with annealing-free $\mathrm{ZnO}$ and $\mathrm{Al}$ layers," ACS Applied Materials \& Interfaces, vol. 9, pp. 22068-22075, 2017.

[108] J. W. Jo, J. W. Jung, S. Bae et al., "Development of self-doped conjugated polyelectrolytes with controlled work functions and application to hole transport layer materials for highperformance organic solar cells," Advanced Materials Interfaces, vol. 3, article 1500703, 2016.

[109] R. Ilmi, A. Haque, and M. S. Khan, "High efficiency small molecule-based donor materials for organic solar cells," Organic Electronics, vol. 58, pp. 53-62, 2018.

[110] S. Liu, J. Yuan, W. Deng et al., "High-efficiency organic solar cells with low non-radiative recombination loss and low energetic disorder," Nature Photonics, vol. 14, pp. 300-305, 2020.

[111] L. Chunyan, Q. Nailiang, S. Yanna et al., "All-small-molecule organic solar cells based on a fluorinated small molecule 
donor with high open-circuit voltage of $1.07 \mathrm{~V}$," Frontiers in Chemistry, vol. 8, p. 329, 2020.

[112] B. Qiu, Z. Chen, S. Qin et al., "Highly efficient all-smallmolecule organic solar cells with appropriate active layer morphology by side chain engineering of donor molecules and thermal annealing," Advanced Materials, vol. 32, no. 21, article 1908373, 2020.

[113] R. Zhou, Z. Jiang, C. Yang et al., “All-small-molecule organic solar cells with over $14 \%$ efficiency by optimizing hierarchical morphologies," Nature Communications, vol. 10, article 5393, 2019.

[114] D. Hu, Q. Yang, H. Chen et al., "15.34\% efficiency all-smallmolecule organic solar cells with an improved fill factor enabled by a fullerene additive," Energy \& Environmental Science, vol. 13, no. 7, pp. 2134-2141, 2020.

[115] R. Yu, H. Yao, and J. Hou, "Recent progress in ternary organic solar cells based on nonfullerene acceptors," Advanced Energy Materials, vol. 8, no. 28, article 1702814, 2018.

[116] V. Lami, Y. J. Hofstetter, J. F. Butscher, and Y. Vaynzof, "Energy level alignment in ternary organic solar cells," Advanced Electronic Materials, vol. 6, no. 8, article 2000213, 2020.

[117] M. Zhang, J. Wang, X. Ma et al., "Review on smart strategies for achieving highly efficient ternary polymer solar cells," APL Materials, vol. 8, article 090703, 2020.

[118] Z. Xiao, X. Jia, and L. Ding, "Ternary organic solar cells offer $14 \%$ power conversion efficiency," Science Bulletin, vol. 62, no. 23, pp. 1562-1564, 2017.

[119] M. Ren, G. Zhang, Z. Chen et al., "High-performance ternary organic solar cells with controllable morphology via sequential layer-by-layer deposition," ACS Applied Materials \& Interfaces, vol. 12, no. 11, pp. 13077-13086, 2020.

[120] L. Zhan, S. Li, T. Lau et al., "Over 17\% efficiency ternary organic solar cells enabled by two non-fullerene acceptors working in an alloy-like model," Energy \& Environmental Science, vol. 13, no. 2, pp. 635-645, 2020.

[121] Q. An, J. Wang, W. Gao et al., "Alloy-like ternary polymer solar cells with over $17.2 \%$ efficiency," Science Bulletin, vol. 65, no. 7, pp. 538-545, 2020.

[122] C. Yan, S. Barlow, Z. Wang et al., "Non-fullerene acceptors for organic solar cells," Nature Reviews Materials, vol. 3, no. 3, article 18003, 2018.

[123] J. Hou, O. Inganäs, R. H. Friend, and F. Gao, "Organic solar cells based on non-fullerene acceptors," Nature Materials, vol. 17, no. 2, pp. 119-128, 2018.

[124] S. Schuller, P. Schilinsky, J. Hauch, and C. J. Brabec, "Determination of the degradation constant of bulk heterojunction solar cells by accelerated lifetime measurements," Applied Physics A: Materials Science \& Processing, vol. 79, no. 1, pp. 37-40, 2004.

[125] C. H. Peters, I. T. Sachs-Quitana, J. P. Kastrop, S. Beaupre, M. Leclerc, and M. D. McGehee, "High Efficiency Polymer Solar Cells with Long Operating Lifetimes," Advanced Energy Materials, vol. 1, no. 4, pp. 491-494, 2011.

[126] S. B. Sapkota, A. Spies, B. Zimmermann, I. Dürr, and U. Würfel, "Promising long-term stability of encapsulated ITO-free bulk-heterojunction organic solar cells under different aging conditions," Solar Energy Materials \& Solar Cells, vol. 130, pp. 144-150, 2014.

[127] D. Lee, J. Kim, G. Park, H. Bae, M. An, and J. Kim, "Enhanced operating temperature stability of organic solar cells with metal oxide hole extraction layer," Polymers, vol. 12, no. 4, p. 992, 2020.

[128] H. R. Yeom, J. Heo, G.-H. Kim et al., “Optimal top electrodes for inverted polymer solar cells," Physical Chemistry Chemical Physics, vol. 17, no. 3, pp. 2152-2159, 2015.

[129] Q. An, F. Zhang, J. Zhang, W. Tang, Z. Deng, and B. Hu, "Versatile ternary organic solar cells: a critical review," Energy \& Environmental Science, vol. 9, no. 2, pp. 281-322, 2016.

[130] X. Liu, C. Zhang, S. Pang et al., “Ternary all-polymer solar cells with $8.5 \%$ power conversion efficiency and excellent thermal stability," Frontiers in Chemistry, vol. 8, 2020.

[131] S. Kim, M. Jahandar, J. H. Jeong, and D. C. Lim, "Recent progress in solar cell technology for low-light indoor applications," Current Alternative Energy, vol. 3, no. 1, pp. 3-17, 2019.

[132] S. Yun, Y. Qin, A. R. Uhl et al., "New-generation integrated devices based on dye-sensitized and perovskite solar cells," Energy \& Environmental Science, vol. 11, no. 3, 2018.

[133] F. Bonaccorso, L. Colombo, G. Yu et al., "Graphene, related two-dimensional crystals, and hybrid systems for energy conversion and storage," Science, vol. 347, no. 6217, article 1246501, 2015.

[134] M. Yu, X. Ren, L. Ma, and Y. Wu, "Integrating a redoxcoupled dye-sensitized photoelectrode into a lithium-oxygen battery for photoassisted charging," Nature Communications, vol. 5, no. 1, p. 5111, 2014.

[135] W. Guo, X. Xue, S. Wang, C. Lin, and Z. L. Wang, "An Integrated Power Pack of Dye-Sensitized Solar Cell and Li Battery Based on Double-Sided TiO2Nanotube Arrays," Nano Letters, vol. 12, no. 5, pp. 2520-2523, 2012.

[136] X. Chen, H. Sun, Z. Yang et al., "A novel "energy fiber" by coaxially integrating dye-sensitized solar cell and electrochemical capacitor," Journal of Materials Chemistry A, vol. 2, no. 6, pp. 1897-1902, 2014.

[137] P. Yang, X. Xiao, Y. Li et al., "Hydrogenated ZnO Core-Shell Nanocables for Flexible Supercapacitors and Self-Powered Systems," ACS Nano, vol. 7, no. 3, pp. 2617-2626, 2013.

[138] X. Qifan, R. Xia, C. J. Brabec, and H.-L. Yip, "Recent advances in semi-transparent polymer and perovskite solar cells for power generating window applications," Energy \& Environmental Science, vol. 11, no. 7, pp. 1688-1709, 2018.

[139] Y. Zhu, L. Shu, and Z. Fan, "Recent progress on semitransparent perovskite solar cell for building-integrated photovoltaics," Chemical Research in Chinese Universities, vol. 36, pp. 366-376, 2020.

[140] Z. Hu, J. Wang, X. Ma et al., "A critical review on semitransparent organic solar cells," Nano Energy, vol. 78, article 105376, 2020.

[141] Y. Cui, L. Hong, and J. Hou, "Organic photovoltaic cells for indoor applications: opportunities and challenges," ACS Applied Materials \& Interfaces, vol. 12, no. 35, pp. 3881538828, 2020.

[142] Z. Ding, R. Zhao, Y. Yua, and J. Liu, “All-polymer indoor photovoltaics with high open-circuit voltage," Journal of Materials Chemistry A, vol. 7, no. 46, pp. 26533-26539, 2019.

[143] Y. Cui, H. Yao, T. Zhang et al., " $1 \mathrm{~cm}^{2}$ organic photovoltaic cells for indoor application with over $20 \%$ efficiency," Advanced Materials, vol. 31, no. 42, 2019.

[144] Y. Bai, R. Yu, Y. Bai et al., "Ternary blend strategy in benzotriazole-based organic photovoltaics for indoor application," Green Energy \& Environment, 2020. 